\title{
Identification of a Ciliopagurus strigatus (Herbst, 1804) species-complex, with description of a new species from French Polynesia (Crustacea, Decapoda, Anomura, Diogenidae)
}

\author{
Joseph POUPIN \\ Institut de Recherche de l'École navale (IRENav), \\ BP 600, F-29240 Brest Armée (France) \\ joseph.poupin@ecole-navale.fr \\ Maria Celia MALAY \\ University of Florida, Department of Zoology, \\ and Florida Museum of Natural History, \\ Gainesville, FL 32611 (USA) \\ malay@flmnh.ufl.edu
}

KEY WORDS

Crustacea,

Decapoda,

Diogenidae,

Ciliopagurus,

sibling species, species-complex, Indo-West Pacific, new species.
Poupin J. \& Malay M. C. 2009. - Identification of a Ciliopagurus strigatus (Herbst, 1804) species-complex, with description of a new species from French Polynesia (Crustacea, Decapoda, Anomura, Diogenidae). Zoosystema 31 (2) : 209-232.

\section{ABSTRACT}

Four hermit crabs of the genus Ciliopagurus are recognized as a complex of species named the "strigatus complex". They are found in the low intertidal or shallow waters of the Indo-West Pacific. Ciliopagurus strigatus (Herbst, 1804) is characterized by striped legs and chelae with alternate yellow and red transverse colour bands. It is commonly found on reef habitats and is reported from the Red Sea to French Polynesia. Ciliopagurus tricolor Forest, 1995 is reported with certainty from East Africa to Réunion Island, C. vakovako Poupin, 2001 is endemic to the Marquesas Islands, and C. galzini n. sp. is described as a new species from specimens collected in the Tuamotus. Within the 17 extant species of the genus Ciliopagurus, these four species are distinct by the aspect of the ocular acicle with 3-5 terminal spines instead of usually 1 or 2 in the other species, a few morphometric characters, and by their vertical distribution, from intertidal to about $20 \mathrm{~m}$, whereas all the other species are usually collected deeper. The species of the "strigatus complex" are morphologically very similar and can be separated with confidence only by their coloration. All of them have similar colour patterns of transverse bands on the chelipeds and walking legs, but each species can be easily recognized by the distinct colour and/or disposition of these bands. The appraisal of these colour differences as valuable specific indicators is confirmed by phylogenetic analysis of mitochondrial and nuclear DNA sequences. 
MOTS CLÉS

Crustacea,

Decapoda,

Diogenidae,

Ciliopagurus, espèces jumelles, complexe d'espèces, Indo-ouest Pacifique, espèce nouvelle.

\section{RÉSUMÉ}

Reconnaissance d'espèces jumelles proches de Ciliopagurus strigatus (Herbst, 1804), avec la description d'une nouvelle espèce de Polynésie française (Crustacea, Decapoda, Anomura, Diogenidae).

Quatre Bernard-l'ermite du genre Ciliopagurus sont identifiés comme appartenant à un complexe d'espèces nommé "complexe strigatus». Ils sont récoltés dans le bas de la zone intertidale et par petits fonds dans tout l'Indo-ouest Pacifique. Ciliopagurus strigatus (Herbst, 1804) est caractérisé par des rayures sur les pinces et les pattes ambulatoires. Il est commun des récifs, depuis la mer Rouge jusqu’à la Polynésie française. Ciliopagurus tricolor Forest, 1995 est connu avec certitude de l'Afrique orientale à l'île de la Réunion, C. vakovako Poupin, 2001 est endémique des îles Marquises, et $C$. galzini n. sp. est décrit comme une nouvelle espèce à partir de spécimens récoltés dans les Tuamotu. Parmi les 17 espèces actuelles du genre Ciliopagurus, ces quatre espèces sont distinctes par: l'écaille oculaire terminée par 3-5 épines, au lieu de 1 ou 2 épines pour toutes les autres espèces, quelques caractères biométriques, et leur distribution verticale, depuis le milieu intertidal jusqu'à environ $20 \mathrm{~m}$, alors que toutes les autres espèces sont généralement récoltées plus profond. Elles sont morphologiquement très proches et ne peuvent être reconnues facilement que par leur coloration. Toutes ont des bandes colorées transverses sur les pinces et les pattes ambulatoires mais chaque espèce présente des couleurs distinctes ou une disposition particulière des bandes. L'utilisation de ces différences de coloration comme caractère spécifique valable est confirmée par des analyses phylogénétiques de l'ADN mitochondrial et nucléaire.

\section{INTRODUCTION}

The genus Ciliopagurus Forest, 1995 includes hermit crab species that possess a stridulating apparatus on the dorso-mesial face of the chelae. Within the Diogenidae Ortmann, 1892 only two other genera have a similar structure: Trizopagurus Forest, 1952 and Strigopagurus Forest, 1995. Ciliopagurus is at once distinguished from the latter two genera by the presence of transverse ciliated striae on the chelipeds and ambulatory legs and by a set of other characters that are detailed in Forest (1995a: 17). Sixteen species of Ciliopagurus were listed in Forest (1995a) and an additional species was described from the Marquesas Islands by Poupin (2001). Two fossil species are also known, one described by Forest (1995b) and another by Bakel et al. (2003), for a total of 19 species in the genus. All extant species are tropical; 16 species are distributed in the Indo-West Pacific and only one in the eastern Atlantic.

This study focuses on the species of Ciliopagurus found in littoral or shallow waters, and that have a truncated ocular acicle terminating in 2-5 spines. This group, herein defined as the "strigatus complex", includes four species: C. strigatus (Herbst, 1804), C. tricolor Forest, 1995, C. vakovako Poupin, 2001, and C. galzini n. sp. described herein from the Tuamotus. All four species are characterized by coloured striae on chelipeds and ambulatory legs. Their morphology is so similar that they can be distinguished confidently only by the disposition of the coloured striae, a character that unfortunately disappears in alcohol after preservation.

Diagnoses are given for all species of the "strigatus complex", along with a key to the species. Clarification of the taxonomic status of Ciliopagurus strigatus (Herbst, 1804) pending since Sakai (1999: 10; see 
also Poupin 2001: 297) is presented. The conclusion that colour morphs represent valid taxonomic species is discussed taking into consideration morphometric characters, DNA data, and geographic distribution.

\section{MATERIALS AND METHODS}

\section{COLLECTIONS}

Specimens examined for this study are deposited in the Muséum national d'Histoire naturelle, Paris (MNHN) and the Florida Museum of Natural History, University of Florida (UF). A few additional specimens have been examined from other collections: Natur-Museum Senckenberg, Frankfurtam-Main (MS), Western Australian Museum, Perth (WAM), Zoological Reference Collection of the Raffles Museum of Biodiversity Research, National University of Singapore (ZRC), Museum für Naturkunde, Berlin (ZMB), Naturalis, Nationaal Natuurhistorisch Museum, Leiden (NNML), Coastal Branch of Natural, History Museum and Institute, Chiba (CMNH).

Most of the specimens have been collected in the last 10 years in the Indo-West Pacific and have retained traces of coloration. Photographs of live coloration are also available for all species of this complex.

For the phylogenetic analysis of DNA sequences Dardanus lagopodes (Forsskål, 1775), Strigopagurus poupini Forest, 1995, and Ciliopagurus hawaiiensis (McLaughlin \& Bailey-Brock, 1975) were used as outgroups, from specimens collected in French Polynesia (Tikehau I.) and the northwestern $\mathrm{Ha}$ waiian Islands (French Frigate Shoals).

Collections were made in the low intertidal area or by snorkeling/scuba diving in shallow waters $(0-40 \mathrm{~m})$. A few samples were obtained by dredging around the Marquesas Islands during the expeditions of the fishing vessel Marara in 1990, and the MUSORSTOM 9 cruise in 1997. Details of these expeditions with full lists of the stations are in Poupin (1996) and Richer de Forges et al. (1999).

The shells occupied by the hermit crabs have been determined by the following malacologists: G. Paulay, R. von Cosel and J. Tröndlé.

\section{MORPHOMETRIC CHARACTERS}

The following measurements were made with a digital caliper to the nearest $0.01 \mathrm{~mm}$ : shield length $(\mathrm{sl})$, from the tip of rostrum to posterior edge of the shield, and is used as standard size for all specimens examined; distal antennal segment length; ocular peduncle length and diameter of cornea; left chela length and height and length of its dactyl; left third pereiopod (P3) dorsal lengths of dactyl, propodus, carpus, and merus. Number (n) of observations used to calculate means and ranges of the measurements are: $C$. strigatus, $\mathrm{n}=9$; C. vakovako, $\mathrm{n}=18$; C. tricolor, $\mathrm{n}=11$; C. galzini $\mathrm{n}$. sp., $\mathrm{n}=5$. Comparative measurements have been done on C. krempfi (Forest, 1952), $\mathrm{n}=17$, on the material from the Marquesas Is. reported by Poupin (2001). Statistic analyses were made using the program STATISTICA (Statsoft ${ }^{\odot}$ ), and includes comparison of two means (parametric $t$ test and non-parametric Mann-Whitney U test) and comparison of several means (parametric ANOVA and non-parametric Kruskall-Wallis ANOVA). Differences between means were considered statistically significant at a $\mathrm{P}<0.05$.

\section{MOLECULAR METHODS}

DNA was extracted from muscle tissue using DNAzol and proteinase $\mathrm{K}$ following the protocol given in Meyer (2003). Two mitochondrial gene regions (cytochrome oxidase $\mathrm{C}$ subunit I/COI and 16S rDNA) and one nuclear region (Histone $3 / \mathrm{H} 3$ ) were amplified and sequenced for this study. The length of the gene fragments and the PCR primers used are as follows: COI: 627 base pairs (bp); primers dgLCO (5'-GGT CAA CAA ATC ATA AAG AYA TYG G-3') and dgHCO (5'-TAA ACT TCA GGG TGA CCA AAR AAY CA-3'; primers modified from Folmer et al. 1994). 16S: 457 bp; primers 16SAR (5'-CGC CTG TTT ATC AAA AAC AT-3') and 16SBR (5'-GCC GGT CTG AAC TCA GAT CAC GT-3'; Palumbi 1996). H3: 291 bp; primers H3af (5'-ATG GCT CGT ACC AAG CAG ACV GC-3') and H3ar (5'-ATA TCC TTR GGC ATR ATR GTG AC-3'; Colgan et al. 1998). PCR thermocycler profiles for COI and 16S were as in Meyer (2003), while the PCR profile for $\mathrm{H} 3$ followed Pérez-Losada et al. (2004). PCR amplification products were purified 
using the exo-sap cleanup protocol, then sequenced in a 96-well format using BigDyeTerminator cycle sequencing reactions. Electrophoresis was done using ABI-3730-XL. PCR product cleanup and sequencing were done by the University of Florida's Interdisciplinary Center for Biotechnology Research (ICBR) sequencing facility.

\section{SEQUENCE ANALYSIS}

Chromatograms of the sequences were manually checked and edited using the software Sequencher ver. 4.2 (Gene Codes). Sequences are available in GenBank under accession nos. EF683559-EF683579 and EU334635-EU334658. Twenty-one individuals were sequenced for the COI gene, while a subset of 11 individuals (including two individuals for each of the four ingroup taxa) was sequenced for all three gene regions. Phylogenetic analyses were done both for the larger taxonomic set of 21 individuals and the three-gene 11-taxon subset.

For the three-gene dataset, we evaluated the appropriateness of combining the genetic data from different gene regions into a single concatenated analysis. Combining datasets that give conflicting signals (due, for instance, to different phylogenetic histories or evolutionary dynamics) could result in misleading phylogenies. One common statistical method used to assess data combinability is the parsimony-based incongruence length difference (ILD) test (Farris et al. 1994). We used PAUP* version $4.0 \mathrm{~b} 10$ to perform the ILD test simultaneously for the three data partitions. The results did not reveal significant incongruence in the data gene trees. However, the usefulness of the ILD test for evaluating data combinability has been called into question (e.g., Yoder et al. 2001; Barker \& Lutzoni 2002; Grant \& Kluge 2003). In order to address these concerns and to explore our data further, we performed separate maximum likelihood (ML) heuristic searches for each of the three gene regions and assessed branch support by performing 1000 bootstrap replicates. The resulting gene trees were not in conflict with each other or with the concatenated analysis (data not shown). Based on this evidence, we decided that a combined analysis was appropriate.

For both the COI-only dataset and three-gene concatenated dataset, phylogenies were estimated using maximum parsimony (MP), maximum likelihood (ML), and Bayesian methods. Parsimony and likelihood analyses were done using the program PAUP* ver. 4.0b10 (Swofford 2002), while MrBayes v3.1.2 (Ronquist \& Huelsenbeck 2003) was used to implement Bayesian methods. In all analyses, all sites were weighted equally, characters were unordered, and gaps were treated as missing data. Prior to implementing ML analyses we determined the simplest model of evolution that best fit the data using the Akaike Information Criterion (AIC) as implemented by the program Modeltest 3.6 (Posada \& Crandall 1998). The model that was selected for the COI-only dataset was a $\mathrm{HKY}+\mathrm{I}+\mathrm{G}$ model of sequence evolution, while for the three-gene concatenated dataset a TVM+I+G model was selected. In the MP and ML analyses, heuristic searches started with random addition of taxa replicated 1000 times using the tree-bisectionreconnection (TBR) branch-swapping algorithm and branch support by bootstrap support values, which were calculated as above with 1000 replicates. The Bayesian analyses were run on two independent chains for 1 million generations each; each chain was sampled every 100 generations. In each chain the initial 30000 generations were discarded as the burn-in phase. Bayesian posterior probabilities were calculated based on the remaining trees.

\section{SYSTEMATICS}

\section{Family Diogenidae Ortmann, 1892}

\section{Genus Ciliopagurus Forest, 1995}

\section{DEFINITION OF THE "STRIGATUS COMPLEX" OF SPECIES}

Morphological characters used to define this complex of species of Ciliopagurus are: 1) ocular acicle truncated and distally armed with 3-5 (rarely 2) terminal spines, instead of being acute with 1 or 2 (rarely 3 ) terminal spines as in other congeners; 2 ) relatively short ocular peduncles about 0.7 shield length; 3) relatively short distal segments of antennular peduncles about 0.25 shield length; 4) relatively low P3 dactyl/propodus ratio, about 1.05; and 5) use of narrow-apertured shells (e.g., Conidae or 
Olividae), and a more flattened cephalothorax.

The four species in this complex are also remarkable in that they live in low intertidal and shallow waters only. Ciliopagurus strigatus is found from the low intertidal to about $20 \mathrm{~m}$; C. tricolor is intertidal to subtidal, with the deepest record at $30 \mathrm{~m}$; C. vakovako occurs from the intertidal to $10-20 \mathrm{~m}$, with a single record at $53 / 57 \mathrm{~m}$; and C. galzini n. sp. is from 3-12 m. None of the other Ciliopagurus species are known from the intertidal area and most of them are usually found deeper than $50 \mathrm{~m}$ (see Forest 1995a: 131, fig. 30). In the depth range of 10-20 m Ciliopagurus krempfi Forest, 1952, distributed from East Africa to central Pacific, could co-occur with the species of the "strigatus complex". However, intensive fishing investigations conducted with dredges and traps around the Marquesas Islands have shown that, at least in these islands, C. krempfi is a deep species located in the range of $74-252 \mathrm{~m}$, and that it has been confused in shallower waters (0-57 m) with C. vakovako (Poupin 2001). It is therefore possible that the few unusual records of C. krempfi in the 10-20 m depth range (see Forest 1995a: 59; Hong Kong, $10 \mathrm{~m}$ and Moluccas Islands, $13-18 \mathrm{~m}$ ) could in fact belong to a species of the "strigatus complex".

The distribution of Ciliopagurus shebae Lewinsohn, 1969 in Forest (1995a) was formerly limited to the West Indian Ocean, with a depth range of 55-90 to 90-130 m. Recently, this species has also been reported from Japan and surrounding islands (Kato \& Okuno 2001; Okuno \& Arima 2006; Okuno et al. 2006), with depth range between 20$37 \mathrm{~m}$. Therefore, it appears that the depth range of this species can also overlap with that of shallow water species of the "strigatus complex". However, according to Okuno (pers. comm.), C. shebae specimens collected in Japanese waters were obviously always deeper than those of $C$. strigatus, which are usually found between 5-15 m.

\section{Ciliopagurus strigatus (Herbst, 1804)} (Figs 1A; 2; 3A; 4A; 6-9)

References limited to key references and field guides that illustrate this species in colour. Additional references and full synonymy are in Forest (1995a).
Cancer strigatus Herbst, 1804: 25, pl. 61, fig. 3 [type locality: East Indies].

Trizopagurus strigatus - Forest 1952a: 256; 1952b: 19, figs 5, 14, 21. - Fielding \& Robinson 1987: 78, photo 64. - Haig \& Ball 1988: 177. - Nomura et al. 1988: 123. - Allen \& Steene 1994: 151. - Debelius \& Baensch 1994: 610. — Takeda 1994: 197. — Asakura 1995: 352, pl. 93-3. — Tudge 1995: 30. — Gosliner et al. 1996: 225, fig. 819. — Yu \& Foo 1991: 57. Jones \& Morgan 2002: 123. — Laboute \& Richer de Forges 1994: 391.

Ciliopagurus strigatus - Forest 1995a: 49, figs 8a, 9, 10a, 12a, 31a-b, 37c (new generic combination plus full synonymy). — Hoover 1998: 252. — McLaughlin 1997: 221. - Sakai 1999: 10, pl. 2b. - Minemizu 2000: 132. — Debelius 2001: 232. - Kato \& Okuno 2001: 132. - Poupin 2001: 297, figs 1b, 3a, 4. Kawamoto \& Okuno 2003: 74. - Okuno et al. 2006: 150. - McLaughlin et al. 2007: 70.

Not Ciliopagurus strigatus - Forest 1995a: 50 (in part, specimens from the Marquesas) $=$ C. vakovako Poupin, 2001.

TYPE MATERIAL. - East Indies, holotype, dry specimen (ZMB Herbst, 2487).

SHELls. - Conidae: Conus sp.; Conus miles Linnaeus, 1758; Conus striatus Linnaeus, 1758; Conus ?canonicus Hwass in Bruguière, 1792. Columbellidae: Euplica turturina (Lamarck, 1822). Cypraeidae: Cypraea sp., Cypraea caputserpentis Linnaeus, 1758; Cypraea helvola Linnaeus, 1758. Muricidae: Drupa morum (Röding, 1798).

MATERIAL EXAMINED (NB: several depth ranges are indicated for an entire scuba dive operation, sometimes down to $40 \mathrm{~m}$. However, specimens of $C$. strigatus collected during these dives were always caught between approximately 0-15 m). - Réunion I. "Passe de l'hermitage", coll. M. Guillaume, I.2007, 2 o" ơ 2.2, 3.8 mm (MNHN Pg 7759, ơ 3.8 mm DNA H275EF683562). - Near Cap Boucan Canot, outer reef slope, overhangs and black sand patches, 8-14 m, coll. G. Paulay, 16.II.2004, 1 \% $3.5 \mathrm{~mm}$ in Conus, 1 juvenile $2.6 \mathrm{~mm}$ in Euplica turturina (UF Crust 5419). - Coast immediately NE of Cap La Houssaye, $21.01889^{\circ} \mathrm{S}$, $55.23806^{\circ} \mathrm{E}$, rocky coast with basalt bedrock boulders, $0-4 \mathrm{~m}$, coll. G. Paulay, 14.II.2004, 1 ơ $^{3} 3.0 \mathrm{~mm}, 2$ 우 2.0, $2.4 \mathrm{~mm}, 1$ juvenile $2.0 \mathrm{~mm}$ (colour fading, mostly white), all specimens in Conus (UF Crust 5420, DNA H285-EF683571, DNA H286-EF683572); same 1 juvenile $2.3 \mathrm{~mm}$ (UF Crust 5432).

Mauritius I. Cavern, coll. J. Starmer, 1 \$ $2.1 \mathrm{~mm}$ in Conus (UF Crust 5237). 
Christmas I. N coast, $4 \mathrm{~km}$ E of Boat Cave, just outside Thundercliff Cave, dead coral rubble field, under large limestone rocks/rubble, $10 \mathrm{~m}$, coll. L. Kirkendale, 26.XI.1999, 1 ơ 6.9 mm (UF Crust 1941).

Taiwan. Northeast coast, Taipei County, LongDong, fringing reef, 0-3 m, coll. K. Netchy \& R. Lasley, 16.V.2005, 1 ovig. o $4.9 \mathrm{~mm}$, in Conus (UF Crust 7366).

Japan. Ryukyu Is, Okinawa I., Ginowan City, off Okinawa Convention Center, $26.28333^{\circ} \mathrm{N}, 127.71667^{\circ} \mathrm{E}$, reef front, exposed, 1-5 m, coll. G. Paulay, 2.VII.2004, 1 \% $6.2 \mathrm{~mm}$, in Conus miles (UF Crust 7116). - Cape Zanpa, reef on $S$ side of lighthouse, $26.43858^{\circ} \mathrm{N}, 127.71467^{\circ} \mathrm{E}$, inner fringing reef/moat, exposed, 1-2.5 m, coll. G. Paulay, 24.VII.2004, 1 \% $4.1 \mathrm{~mm}$, in Cypraea, 1 o $^{7} 4.4 \mathrm{~mm}$, in Conus (UF Crust 7235). - Ryukyu Is, Ie I., Kanan-zaki, $\mathrm{NW}$ end of island, $26.73917^{\circ} \mathrm{N}, 127.81008^{\circ} \mathrm{E}$, outer reef slope, under rocks, $18-22 \mathrm{~m}$, coll. G. Paulay \& Kinjo, 8.VII.2004, 2 specimens in Conus, 1 o" 3.4 mm, 1 juvenile $1.8 \mathrm{~mm}$ (UF Crust 7001). - Same, area around Crevice \& Daidokutsu Cave, $26.724567^{\circ} \mathrm{S}$, $127.83165^{\circ} \mathrm{E}$, outer reef slope, probably under rock or in cavern, 3-30 m, coll. G. Paulay, 7.VII.2004, $10^{\text {7 }}$ $3.6 \mathrm{~mm}$, in Cypraea, 1 \% $4.1 \mathrm{~mm}$, in Conus (UF Crust 7115, DNA H290-EF683576).

Philippines. Luzon I., Pangasinan Province, Bolinao Municipality, Balingasay, $16.37267^{\circ} \mathrm{N}, 119.84717^{\circ} \mathrm{E}$, slope and fore reef, 6-8 m, coll. M. Malay, 26.VII.2004, 2 ơ ơ $^{7}$ 6.1-6.3 mm, 2 우 5.9-6.1 mm, in Conus miles (UF Crust 6540).

Mariana Is. Supply Reef, $20.13333^{\circ} \mathrm{N}, 144.1^{\circ} \mathrm{E}, 12-20 \mathrm{~m}$, coll. M. Malay et al., 1.IX.2003, $1 \mathrm{o}^{7} 3.5 \mathrm{~mm}$, in Conus (UF Crust 5781). - Maug I., Southern part of E island, inner side, $20.01667^{\circ} \mathrm{N}, 145.23333^{\circ} \mathrm{E}, 4-16 \mathrm{~m}$, coll. M. Malay, 3.IX.2003, 1 ovig. ㅇ $5.3 \mathrm{~mm}$, in Conus, 1 우 $5 \mathrm{~mm}$ in Drupa morum, 1 juvenile (UF Crust 5778). Agrihan I., SE of island, $18.75^{\circ} \mathrm{N}, 145.7^{\circ} \mathrm{E}, 11-15 \mathrm{~m}$, coll. M. Malay, 27.VIII.2003, $10^{7} 6 \mathrm{~mm}$ in Conus, 1 ovig. $95.3 \mathrm{~mm}$ in Conus, 1 o $^{7} 4 \mathrm{~mm}$ in Conus (UF Crust 5774). - Pagan I., coll. M. Malay, 1 ơ 5.1 mm, in Drupa morum (UF Crust 5779). - Alamagan I. SW of island, $17.58333^{\circ} \mathrm{N}, 145.81667^{\circ} \mathrm{E}, 9.5-10.5 \mathrm{~m}$, coll. M. Malay, 10.IX.2003, $10^{7} 5.6 \mathrm{~mm}$ in Conus miles (UF Crust 5772). - Anatahan I., $16^{\circ} \mathrm{N}, 145^{\circ} \mathrm{E}$, coll. M. Malay et al., 1 juvenile (UF Crust 5782). - Saipan I., Bat Cave, 27 m, coll. J. Starmer, 18.XI.1993, 1 o' 5.6 mm in Conus miles (UF Crust 5775). - Same, loose rubble on floor, $27 \mathrm{~m}, 21 . X I .1993,1$ o $3.9 \mathrm{~mm}$ in Conus (UF Crust 5780). - Agingan Point, sewage outfall, $15.1185^{\circ} \mathrm{N}$, $145.68667^{\circ} \mathrm{E}$, exposed on surface of dead limestone rock/ rubble, 21-33 m, coll. L. Kirkendale, 11.VIII.2001, 1 ㅇ $4.3 \mathrm{~mm}$ (UF Crust 1871, DNA IP21-EF683559). Arakane Reef, $15.63333^{\circ} \mathrm{N}, 142.76667^{\circ} \mathrm{E}, 14-17 \mathrm{~m}$, coll. M. Malay, 15.IX.2003, 1 ovig. $95.4 \mathrm{~mm}$ in Conus (UF Crust 5773$)$. - Tinian I., $14.93333^{\circ} \mathrm{N}, 145.63333^{\circ} \mathrm{E}$, 9-11 m, coll. M. Malay, 23.VIII.2003, 1 juvenile in Conus (UF Crust 5776). - Aguijan I., $14.85^{\circ} \mathrm{N}, 145.56667^{\circ} \mathrm{E}$,
13-16 m, coll. M. Malay et al., 17.IX.2003, 1 ơ 2.8 mm, in Conus (UF Crust 5783). - Rota I., $14.15387^{\circ} \mathrm{N}$, 145.25938 ${ }^{\circ} \mathrm{E}, 9-12 \mathrm{~m}$, coll. M. Malay, 19.IX.2003, 3 o $^{7} \mathrm{o}^{7}$ 3.0-4.3 mm, 1 \% $5.3 \mathrm{~mm}$, in Conus sp., Drupa morum, and Cypraea caputserpentis (UF Crust 5777). - Guam I., Tanguisson, fore reef, 8-11 m, coll. G. Paulay, 1 juvenile $2 \mathrm{~mm}$, colour completely gone except black tips on chelae and legs (UF Crust 5920). - Haputo, rubble, 8-10 m, coll. G. Paulay, 8.VII.2003, 2 ơ ơ 2.1, $2.8 \mathrm{~mm}$, in Conus and Cypraea helvola (UF Crust 5972). - Tanguisson, fore reef, 5-20 m, coll. G. Paulay, 23.VI.2003, 1 juvenile (UF Crust 6014). - Tepungan channel tunnel, 0-4 m, coll. G. Paulay, 16.VI.2003, 1 juvenile (UF Crust 6017). — S Orote, under rocks, 18-22 m, coll. G. Paulay, 1 juvenile $1.9 \mathrm{~mm}$, in Cypraea (UF Crust 8706).

Papua New Guinea. Bismarck Archipelago, Sherburne Reef, $3.32389^{\circ} \mathrm{S}, 148.21528^{\circ} \mathrm{E}$, subsided small atoll, outer side, forereef, steep coral slope, 3-40 m, coll. L. Kirkendale, 21.VI.2003, 1 ơ $9.4 \mathrm{~mm}$ in Conus striatus (UF Crust 4801), 1 ovig. $95.2 \mathrm{~mm}$ in Conus (UF Crust 4815). Same, $3.44917^{\circ} \mathrm{S}, 148.08222^{\circ} \mathrm{E}, 3-38 \mathrm{~m}, 21 . \mathrm{VI} .2003$, 1 ovig. $96 \mathrm{~mm}$ in Conus (UF Crust 4844). - Sisi Liu I., W side of Manus I., 6 mi offshore, $2.260278^{\circ}$ S, $146.67278^{\circ} \mathrm{E}$, fore reef, gentle coral slope with abundant Halimeda cover, 1-34 m, coll. L. Kirkendale, 29.VI.2003, 1 \% $2.3 \mathrm{~mm}$, in Conus (UF Crust 6645).

Vanuatu. Sanma Province, Aore I., Aore Point, shore near "Fantastic" dive site $15.5325^{\circ} \mathrm{S}, 167.21417^{\circ} \mathrm{E}$, under and on rubble, $4.5 \mathrm{~m}$, coll. C. Meyer, 23.I.2005, 1 \% $4.7 \mathrm{~mm}$, in Conus?canonicus (UF Crust 8028). - Shefa Province, Epi I., Southern Lamen Bay, $16.59611^{\circ} \mathrm{S}, 168.1675^{\circ} \mathrm{E}$, fringing reef, rubble, 1-3 m, coll. C. Meyer, 8.I.2005, 2 o 9 5.5-7.0 mm, in Conus (UF Crust 8502).

Wallis and Futuna Is. Futuna I., lagoon, Pito area, snorkeling 1-2 m, under rubbles, st CRISP-1, $14.2625^{\circ} \mathrm{S}$, $178.17639^{\circ} \mathrm{E}$, coll. J. Poupin, 9.X.2007, 1 ơ $7.0 \mathrm{~mm}$ (MNHN Pg 7762).

Fiji Is. Lau Group, Nayau I. off shore of Salia Village, fringing reef, coll. T. Bell, 8.X.2003, 1 \$ $6.9 \mathrm{~mm}$ (UF Crust 5510). - Same, 14.X.2003, 1 ovig. $\& 6$ mm (UF Crust 5517).

American Samoa. Tutuila I. outer reef, 3-15 m, coll. V. Bonito, 16.X.2002, 1 o' $6.7 \mathrm{~mm}$ in Cypraea (UF Crust 3247). - Same, 0-2 m, 23.X.2002, 1 ㅇ $4.5 \mathrm{~mm}$ (UF Crust 3270). - Same, Au'asi, $14.2715^{\circ} \mathrm{S}, 170.57283^{\circ} \mathrm{W}$, under rubble, 9-15 m, 19.X.2002, 2 specimens (UF Crust 3258).

Niue I. South Alofi, Opaahi, outer reef slope, under rocks and in substrate under rocks, 6-9 m, coll. B. Holthuis \& G. Paulay, 15.X.1991, 1 o 5 mm, colour completely gone except for black tips on chelae and legs (UF Crust 1886).

Hawaiian Is. Oahu I., off Kahe Point Beach Park, outer reef slope, under rocks?, 11-15 m, coll. J. Earle, J. Hoover \& G. Paulay, 24.II.2006, 1 juvenile $1.6 \mathrm{~mm}$ (UF Crust 8771, DNA H288-EF683574). — Molokai 


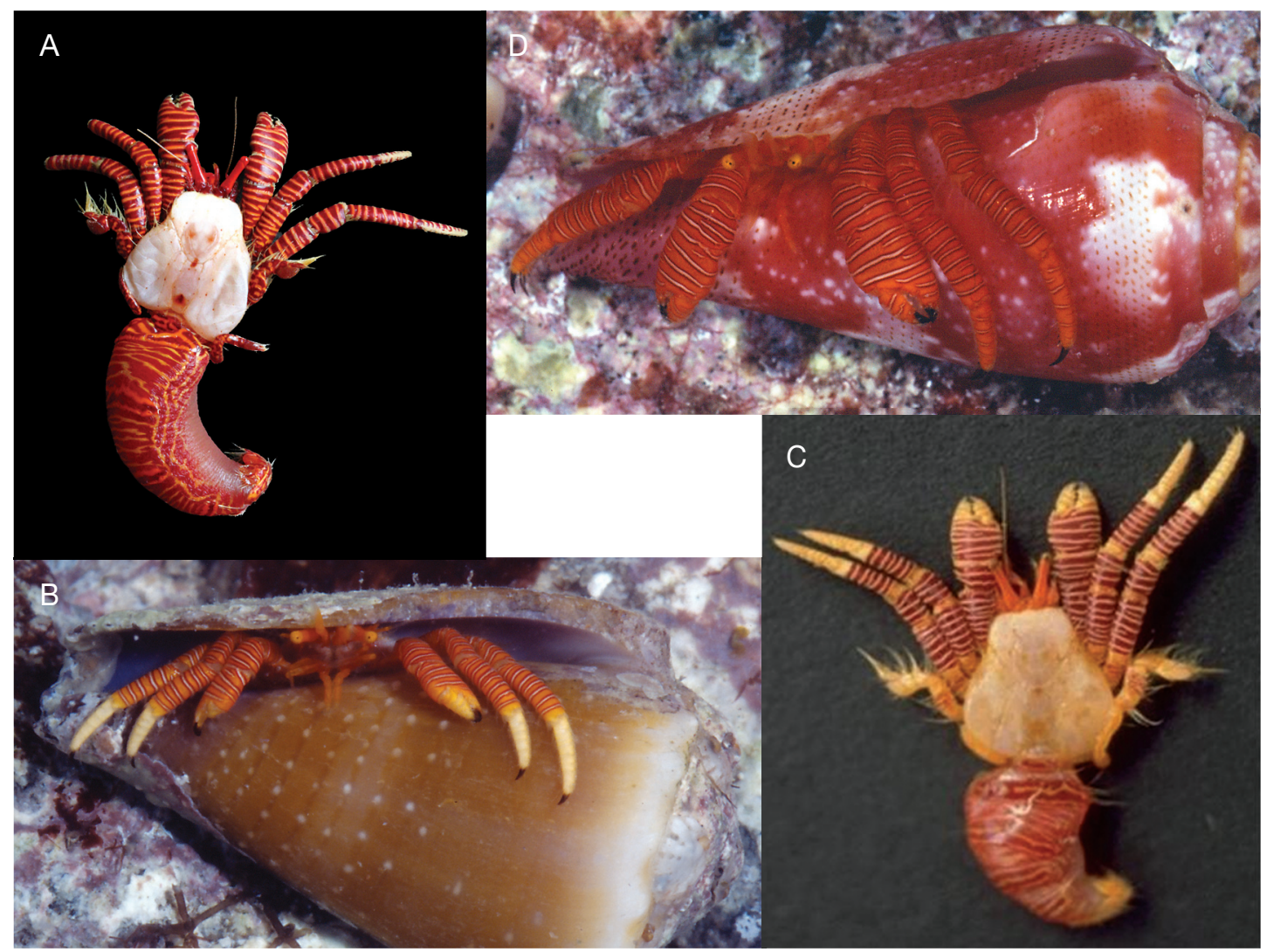

FIG. 1. - Live colorations: A, Ciliopagurus strigatus (Herbst, 1804), Futuna I., o 7 mm (MNHN Pg 7762); B, C. tricolor (Forest, 1995), Réunion I., ovig. † 2.9 mm (UF Crust 5433); C, C. vakovako Poupin, 2001, Marquesas Is, holotype ơ 4.3 mm (MNHN 5896); D, C. galzini n. sp., Tuamotus, holotype ơ $3.8 \mathrm{~mm}$ (UF Crust 10901).

I., Kamiloloa, $21.0697^{\circ} \mathrm{N}, 157.00162^{\circ} \mathrm{W}$, fore reef, on dead Pocillopora heads, 5-8 m, coll. V. Bonito, 30.I.2003, 1 individual (UF Crust 3627).

French Polynesia. Society Is, Tahiti I., Lafayette reef, seashore, coll. J. Poupin, 17.X.1996, 1 ơ, $2.8 \mathrm{~mm}(\mathrm{MNHN}$ Pg 5919). —?Tahiti I., 1 ơ 5.3 mm (MNHN Pg 5920). Papeete reef, coll. "abbé Cullieret", VIII.1890, 1 o" $5.9 \mathrm{~mm}$ (MNHN Pg 1745). - Coll. Bredin Expedition, 8.V.1957, 1 $5.3 \mathrm{~mm}$ (MNHN Pg 1746); 1 ơ $5.5 \mathrm{~mm}$, $1+5.9 \mathrm{~mm}$ (MS 5013). - Moorea I. Tiahura reef, coll. M. Monteforte, 26.VI.1982, 1 ơ $4.1 \mathrm{~mm}$ (MNHN Pg 5425). - Tuamotu Is, Rangiroa I., c. $1 \mathrm{~km} \mathrm{~S}$ of NW point of atoll, off Motu Maeherehonae, $14.92867^{\circ} \mathrm{S}$, $147.85783^{\circ} \mathrm{W}$, outer reef slope, under rocks, 6-12 m, coll G. Paulay, 10.XI.2001, 2 ơ $0^{7} 3.3,4.3 \mathrm{~mm}, 1$ ovig. $9.5 \mathrm{~mm}, 1$ ơ $^{7} 3.3 \mathrm{~mm}$, all in Conus (UF Crust 1818, DNA H287-EF683573, H288-EF683574, photo).

Distribution (Fig. 9). - Ciliopagurus strigatus is widely distributed in the Indo-West Pacific, including Red Sea,
Réunion, Mauritius, West coast of India, Sri Lanka, Christmas I., Cocos Keeling Is, NW Australian coast; Vietnam, Indonesia, Taiwan, South Japan (Ryukyu and Izu Is., Izu peninsula), Philippines, Northern Mariana and Guam, Papua New Guinea, East Australia (Queensland), Chesterfields, New Caledonia, Vanuatu, Fiji, American Samoa, Niue, Hawaii, French Polynesia (Society and Tuamotu Is). Its northernmost latitude is $34^{\circ} 53^{\prime} \mathrm{N}$, at Izu peninsula (water temperature influenced here by warm Kuroshio current); its southernmost latitude is about $27^{\circ} \mathrm{S}$, Moreton Bay (Queensland). It is collected from low intertidal to about $20 \mathrm{~m}$.

DiagnOSIs. - Ocular peduncles 0.61-0.74 times as long as shield (average 0.68). Distal segment of antennular peduncle 0.21-0.29 times as long as shield (average 0.25). Ocular acicles with 3 or 4 terminal spines. Chelipeds equal; outer face of chela with 3 complete transverse striae, striae smooth or with minute spinules. Chela 0.70-1.03 times as long as shield (average 0.90 ); ratio of height to length 
0.61-0.75 (average 0.68); fingers 0.48-0.61 times as long as chela (average 0.54). Main stridulating area with 9-11 parallel corneous crests, distally rounded or acute; 6th to 8th (from dorsal margin) crest longest, $0.33-0.50$ times as long as stridulating area. Merus of cheliped without prominent tubercle on ventral face. Dactyl of third ambulatory leg 0.88-1.09 times as long as propodus (average 1.03). Posterior lobes of telson subequal, unarmed or with 1 or 2 inconspicuous spines on terminal margins.

Coloration (Fig. 1A). - Antennular and antennal peduncles orangish-red; ocular peduncles red, cornea black. Chelipeds (Fig. 3A) and ambulatory legs (Fig. 4A) with bright red rings, alternating with narrower yellow rings; red rings present on chelae (including fingers), dactyls, propodi, carpi and meri. Propodi of ambulatory legs each with a distal red ring along anterior margin and 5 or 6 subsequent red rings (sometimes divided by yellow lines). Shield pure white; abdomen red with a pattern of undulating yellow lines.

\section{CLARIFICATION OF THE TAXONOMIC STATUS} OF CANCER STRIGATUS HERBST, 1804 (Fig. 2) The type specimen of Cancer strigatus is part of $\mathrm{J}$. F. W. Herbst's collection housed in ZMB. This is a dry specimen in its shell (Conus), photographed in Sakai (1999: pl. 2b) and also in this work (Fig. 2A). It is totally discoloured but the colour pattern is available in Herbst's original description (pl. 61, fig. 3) reproduced here on Figure 2B. When preparing his work Sakai (1999) corresponded with Prof. J. Forest and inserted this comment for the holotype of C. strigatus (p. 10): "The present holotype differs from specimens identified as this species by Forest (1995). A revision of the identity of this new material will be undertaken by J. Forest (pers. comm.), so that the whole case is left here at it is."

According to J. Forest (pers. comm.), the transverse striae on the cheliped appear tuberculated in the photograph published by Sakai (1999). This is an important character used in his work (Forest 1995a: 46, key) to split the genus Ciliopagurus into two subequal groups of species: group 1, with eight species that have no tubercles on the transverse striae of the chelipeds, including C. strigatus; group 2, with seven species that have tubercles on these transverse striae. Based on the impression that tubercles are present in Sakai's (1999) photograph, J. Forest considered that the type specimen of $C$. strigatus could not be included in group 1 and was probably conspecific with one species of group 2, possibly C. alcocki Forest, 1995 or C. hawaiiensis.

To clarify the taxonomic status of $C$. strigatus, detailed digital photographs of the type specimen were obtained for this work via the curator of $\mathrm{ZMB}$ collections. They show that the tuberculated aspect of the striae on the chelipeds is mostly an artifact due to the presence of crystals and/or dry pieces of varnish on the type specimen (Fig. 2C, D). In addition they confirm that the ocular acicle is truncated with 3 or 4 terminal spines, a characteristic already indicated in 1952 by Prof. Schellenberg, at that time curator of ZMB collections (see Forest 1952b: 22). This kind of ocular acicle is only observed in a few Ciliopagurus species of group 1 whereas group 2 species all have an elongated ocular acicle terminated by 1 or rarely 2 spines. Therefore the type specimens of C. strigatus cannot be conspecific with one species of group 2, as hypothesized by J. Forest.

In conclusion it appears that no tubercules are present on the transverse striae of the chelipeds and the ocular acicles are truncated, each with 3 or 4 terminal spines. Therefore, Forest's (1995a) interpretation of the taxonomic status of $C$. strigatus is considered correct, and is the same as commonly recognized in field guides on the Indo-West Pacific fauna (e.g., Hoover 1998; Debelius 2001; Kato \& Okuno 2001; Jones \& Morgan 2002). This conclusion is reinforced by the fact that species collected at Herbst's time were common littoral species, whereas all Ciliopagurus species of group 2 in Forest (1995a) are living deeper than $100 \mathrm{~m}$. The possibility that Herbst's type specimen belongs to one of the other species of the "strigatus complex" (C. tricolor, C. vakovako, C. galzini n. sp.) does not seem plausible because none are known from the type locality of C. strigatus, "East Indies", and all have a different colour pattern (compare Fig. 2B with Fig. 1B-D).

\section{Ciliopagurus tricolor Forest, 1995}

(Figs 1B; 3B; 4B; 6-9)

Ciliopagurus tricolor Forest, 1995a: 54, figs 8b, 10b, $12 \mathrm{~b}, 31 \mathrm{c}, 37 \mathrm{e}, 40 \mathrm{~b}, 41 \mathrm{a}, \mathrm{b}$ [type locality: Madagascar, Toliara (Tuléar)]. 

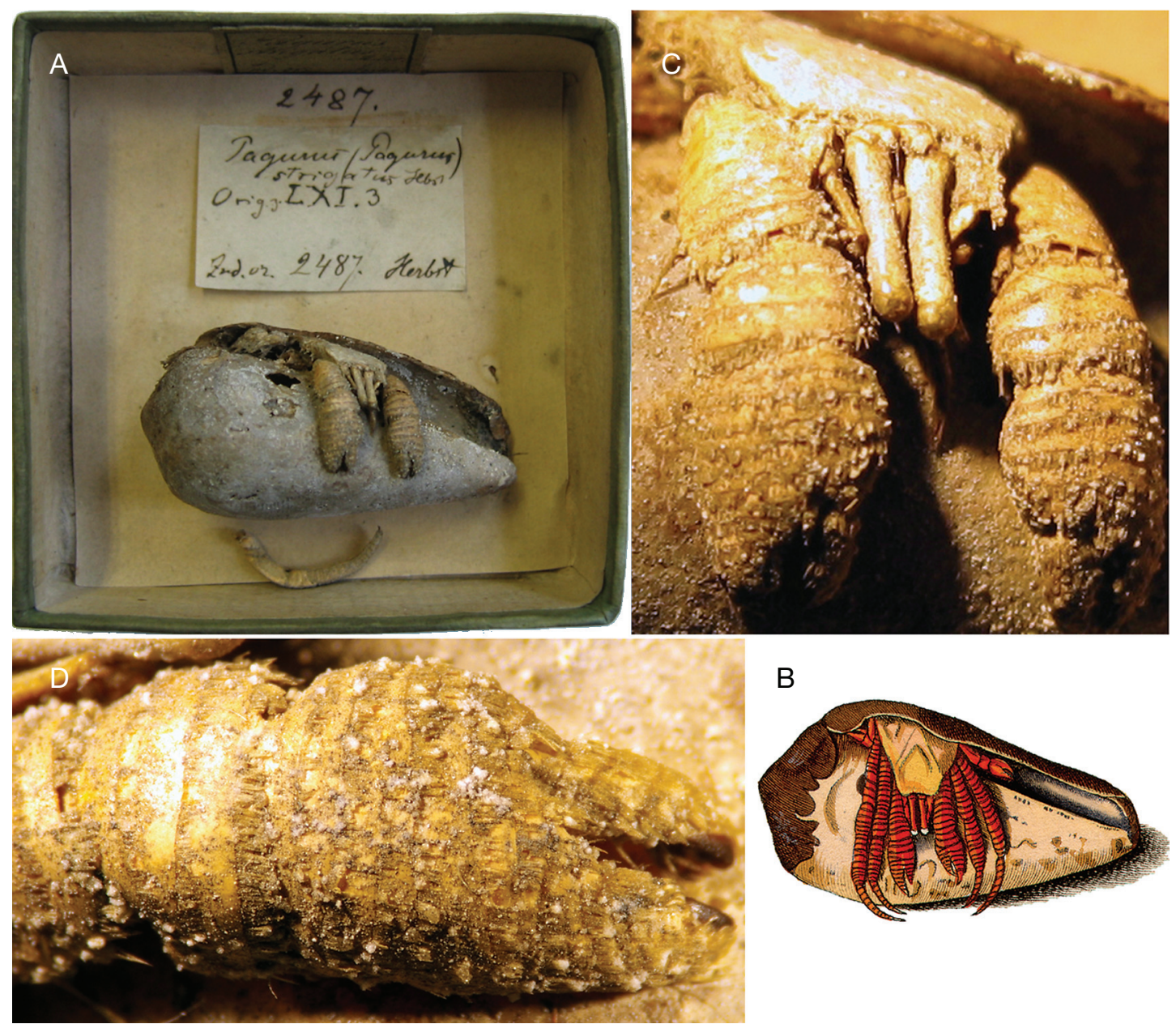

FIG. 2. - Type specimen of Ciliopagurus strigatus (Herbst, 1804): A, C, D, type specimen in ZMB collection; A, general view; C, detail of frontal region; $\mathbf{D}$, detail of right chela, outer view (photographs courtesy of O. Coleman); B, colour pattern as illustrated in Herbst (1804: pl. 61, fig. 3) (courtesy of M. Türkay).

Pagurus (s.s.) strigatus - Hilgendorf 1879: 820, pl. 2, fig. 8 (Mozambique, Ibo Island).

Aniculus strigatus - Barnard 1950: 431, fig. 80a [not C. strigatus (Herbst, 1804)].

Trizopagurus strigatus - Ribes-Beaudemoulin et al. 2002: 69, photo no 6 [not C. strigatus (Herbst, 1804)].

Trizopagurus sp. - Dérijard 1966: 176; 1968: 1241.

Not Ciliopagurus tricolor - Poupin 2005: 9, 23 (Rangiroa) [= C. galzini n. sp.].

TYPe MATERIAL. — Madagascar, Toliara, intertidal, ovig.
O holotype, $6.9 \mathrm{~mm}$ (MNHN Pg 4663); 1 O paratype, 8.0 mm (MNHN Pg 3637).

SHELls. - Conidae: Conus rattus Hwass in Bruguière, 1792 Conus ?omaria Hwass in Bruguière, 1792 or C. ?episcopatus da Motta, 1982.

Material eXamined. — Somalia. Jasiira (Gesira), $20 \mathrm{~km}$ south of Mogadishu, coll. M. Vannini IX-X.1979, 1 o" $5.5 \mathrm{~mm}$ (NNML).

Tanzania. Coll. M. Bacescu, 13.V.1974, 2 ơ ơ 6.5-7.3 mm (MNHN Pg 5426).

Europa I. North reef at low tide, coll. R. Dérijard, IV.1964, 2 ơ ơ 10.1 mm (MNHN Pg 620).

Madagascar. Toliara (= Tuléar), intertidal, coll. R. von 
Cosel, 18.XI.1986, 1 ovig. $96.9 \mathrm{~mm}$ (holotype MNHN Pg 4663); 2 ㅇ 4.2-7.5 mm (MNHN Pg 5427). — Same, intertidal, coll. B. Thomassin, $10^{7} 8.0 \mathrm{~mm}$ (paratype MNHN Pg 3637); 1 ơ 4.9 mm (MNHN Pg 7761).

Réunion I. Passe de l'Ermitage, coll. M. Guillaume, I.2007, 1 ovig. $93.3 \mathrm{~mm}$ (MNHN Pg 7760, DNA H279-EF683565). - NE of Cap La Houssaye, 21.0189² $55.2381^{\circ} \mathrm{E}$, rocky coast with basal bedrocks boulders, 0-4 m, coll. G. Paulay, 14.II.2004, 1 ovig. ㅇ $2.9 \mathrm{~mm}$ (UF Crust 5433, DNA H68-EF683561, photo), 1 ㅇ $2.4 \mathrm{~mm}, 1$ \% $2.9 \mathrm{~mm}, 1 \mathrm{sp}$. in shell (UF Crust 5422, ㅇ 2.4 and $2.9 \mathrm{~mm}$, DNA H280-EF683566, DNA H281-EF683567).

MATERIAL EXAMINED FOR COMPARISON. - Ciliopagurus shebae (Lewinsohn, 1969): Japan. Izu Is. Hachijo-jima I., Nazumado, 25 m, coll. Kato, det. Okuno (reported in Okuno et al. 2006), 25.XI.2000, 1 \& $4.6 \mathrm{~mm}$ (CMNH ZC 00872). - Izu-ohshima I., Akino-hama, 30 m, coll. Arima, det. Okuno (reported in Okuno \& Arima 2006), 27.II.2004, 1 $6.4 \mathrm{~mm}$ (ZC 01734), $36 \mathrm{~m}$, 1.IX.2004, 1 ovig. ㅇ $6.5 \mathrm{~mm}$ (ZC 02122), $23 \mathrm{~m}, 1 . \mathrm{IX} .2004,1 \mathrm{O}^{7}$ $3.9 \mathrm{~mm}$ (ZC 02123), $30 \mathrm{~m}, 2 . I X .2004,1$ ovig. ㅇ $5.6 \mathrm{~mm}$ (ZC 02124).

Distribution (Fig. 9). - West Indian Ocean, approximately between $2^{\circ} \mathrm{N}-26^{\circ} \mathrm{S}, 32-55^{\circ} \mathrm{E}$ : Somalia (Jasiira reef, Mogadishu); Kenya (Mombassa); Tanzania (Paje reef, Zanzibar Island); Mozambique (Ibo I. and Delagoa Bay); Europa I.; Madagascar (Tuléar = Toliara); Réunion. The species is usually collected from the intertidal to about $5 \mathrm{~m}$, with a single record at $30 \mathrm{~m}$ (Mombassa, in Forest 1995a). Forest (1995a: 55, 59) has also reported, with some question, a single specimen from Chagos I., central Indian Ocean but this record must be confirmed by observations of living coloration of more specimens from this place.

DiAGNOSIs. - Ocular peduncles 0.57-0.80 times as long as shield (average 0.67). Distal segment of antennular peduncle 0.21-0.30 times as long as shield (average 0.25). Ocular acicles truncated with 2-5 terminal spines. Chelipeds equal; outer face of palm of chela with 3 complete transverse striae, a posterior stria interrupted in ventral half of the palm, and 2 additional short striae situated in ventral half between striae 1-2 and 2-3. These striae are smooth or with minute spinules. Chela 0.78-1.08 times as long as shield (average 0.88 ); ratio of height to length 0.64-0.80 (average 0.71); fingers 0.49-0.63 times as long as chela (average 0.54 ). Main stridulating area with 11 or 12 parallel corneous crests, distally acute; 7 th to 8 th (from dorsal margin) crests longest, 0.4-0.5 times as long as stridulating area. Merus of cheliped without prominent tubercle on ventral face. Dactyl of third ambulatory leg 0.97-1.22 times as long as propodus (average 1.09). Posterior lobes of telson subequal, unarmed or with 1-3 inconspicuous spines on terminal margins.
Coloration (Fig. 1B). - Antennular and antennal peduncles orangish-red; ocular peduncles orangish-red, cornea pale orange (black on preserved specimens). Chelipeds (Fig. 3B) and ambulatory legs (Fig. 4B) with composite coloured rings, made of one white bluish median band, flanked by two bright red rings; these composite rings are set against an orange background. Chelipeds with composite rings disposed on meri, carpi, and palms of chelae; fingers of chelae almost uniformly pale orange, without composite coloured rings. Ambulatory legs with composite coloured rings on meri, carpi and propodi; dactyls pale orange without composite coloured rings; terminal claws black. Shield white; live coloration of the abdomen unknown, abdomen uniformly white after three weeks in preservative.

\section{REMARKS}

Morphological variations observed on the material examined include unusual armament of the ocular acicle. On the smallest specimen (sl $2.2 \mathrm{~mm})$ of $C$. tricolor only one terminal spine is present. Identification of juvenile specimens based on this character can sometimes be erroneous because of this variation.

Ciliopagurus tricolor is distinguishable by the absence of coloured rings on fingers of chelae and dactyls of ambulatory legs. In the "strigatus complex" this character is also observed in C. vakovako. However, the two species can be easily separated by the aspect of the coloured rings disposed on the remaining part of the chelae and ambulatory legs (compare Figs 3B, C and 4B, C): in C. tricolor the rings are composite, with a bluish white median band flanked by two reds rings; whereas in C. vakovako these rings are uniformly red.

Without the help of coloration Ciliopagurus tricolor is hardly distinct from C. strigatus. Forest (1995a: 58) tentatively used biometric measurements to separate them. He indicated that the dactyl of the chelae is about as long as the palm in C. tricolorversus clearly shorter in C. strigatus and that the dactyl of $\mathrm{P} 3$ longer is $C$. tricolor (P3 dactyl/propodus greater in $C$. tricolor than in C. strigatus). However, similar measurements made for this study have failed to confirm the statistical validity of these differences $(\mathrm{P}<0.05)$ because of large intraspecific variations (see morphometric results and Table 1). Forest (1995a: 58, fig 37c, e) also indicated the presence of an additional stria on the stridulating apparatus 

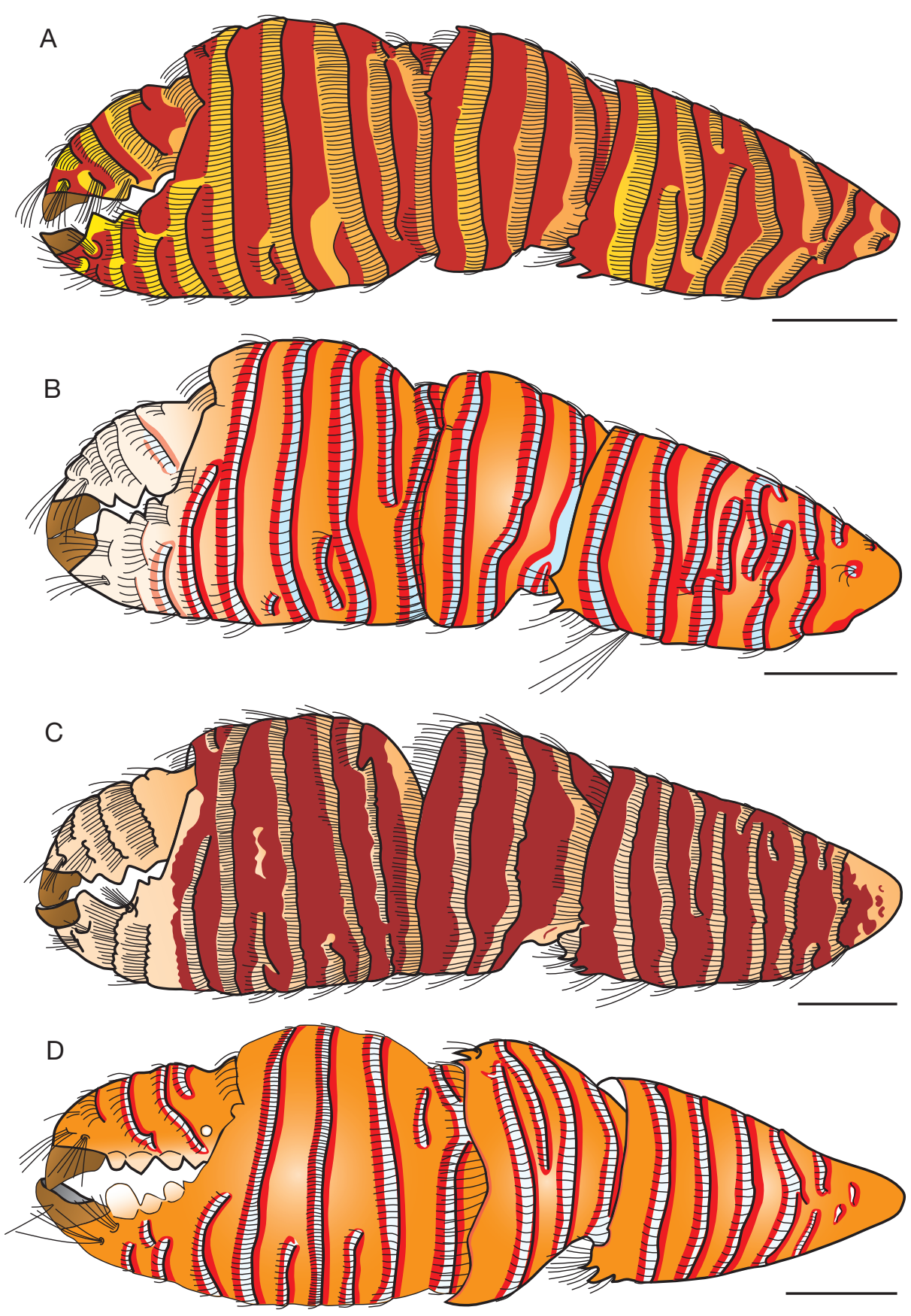

FIG. 3. - Left cheliped colour pattern, outer view: A, Ciliopagurus strigatus (Herbst, 1804), ơ 3.8 mm, Réunion I. (MNHN Pg 7759); B, C. tricolor (Forest, 1995), ovig. o $3.3 \mathrm{~mm}$, Réunion I. (MNHN Pg 7760); C, C. vakovako Poupin, 2001, holotype ơ 4.3 mm, Marquesas Is (MNHN Pg 5896); D, C. galzini n. sp., holotype ơ 3.8 mm (UF Crust 10901). Scale bars: 1 mm. 
of $C$. tricolor but this difference is size-related and is not confirmed in this study by careful comparison of similarly-sized specimens of the two species.

By its coloration Ciliopagurus tricolor is closely related to C. shebae (Lewinsohn, 1969) another species in the genus with similar composite coloured rings on the chelae and ambulatory legs. Ciliopagurus shebae was reported by Forest (1995a) in the Western Indian Ocean (Red Sea, Madagascar, Réunion, Seychelles). Its geographic range has recently been extended to Japan (Minemizu 2000: 132; Kato \& Okuno 2001: 75; Okuno \& Arima 2006: 32, fig. 2h; Okuno et al. 2006: 149, fig. 2 pl. 2b), with several specimens illustrated in colour. Several of these Japanese specimens were examined during this study for comparison with $C$. tricolor (see comparison specimens in Material examined). Despite almost identical colour patterns on the chelae and ambulatory legs, the two species can easily be differentiated by: 1) the aspect of ocular acicle usually with 2-5 spines in C. tricolor and 1 (rarely 2 or 3 ) in C. shebae; 2) morphometric differences that are statistically significant $(\mathrm{P}<0.05)$ : shorter ocular peduncle in $C$. tricolor (mean ratio ocular peduncle length/sl 0.67 vs. 0.82 ), shorter chelae (mean of chela length/sl 0.87 vs. 1.05), shorter dactyl of P3 (mean ratio of P3 dactyl/ propodus length 1.09 vs. 1.36); and 3) distinct depth ranges, usually $0-5 \mathrm{~m}$ for $C$. tricolor, and 20-90/130 m for C. shebae.

In Ciliopagurus the tricolor/shebae species pair is comparable to the vakovakolkrempfi pair. In both species pairs the coloration is similar and the first species of each pair (tricolor, vakovako) belongs to the "strigatus complex" while the second (shebae, krempfi) is collected deeper with distinct aspect of ocular acicle and longer ocular peduncles and dactyls of $\mathrm{P} 3$. The relationships of these two species pairs remains to be elucidated. The structural morphology and life habits (inhabiting narrow-apertured shells) of shallow species suggest they form a distinct evolutionary lineage from the deep forms, while the closely matching colour patterns suggest local relationships between shallow and deep pairs. Sequenceable material of the deep species is needed to robustly solve this problem.
Ciliopagurus vakovako Poupin, 2001

(Figs 1C; 3C; 4C; 6-9)

Ciliopagurus vakovako Poupin, 2001: 292, figs 1a, 2a-d, 3b, 4 [type locality: Eiao I., Marquesas Is., French Polynesia],

Ciliopagurus krempfi - Forest 1995a: 59 (in part, only specimens from Marquesas) [not Ciliopagurus krempfi (Forest, 1952)].

Ciliopagurus strigatus - Forest 1995a: 50 (in part, only specimens from Marquesas) [not Ciliopagurus strigatus (Herbst, 1804)].

Type MATERial. - Marquesas Is., Eiao I., 1-2 m, 1 o7 holotype $4.3 \mathrm{~mm}$ (MNHN 5896), Nuku Hiva I., Anao bay. - Nuku Hiva I., 3 o ơ on $^{\prime} 1$ \% paratypes (MNHN Pg 5897). - Ua Huka I., 2 우 paratypes (MNHN Pg 5898); 1 ㅇ paratype (leg to WAM); 2 ơ $0^{\pi}, 2$ 우 paratypes, 1 paratype in shell (leg to ZRC). - Ua Pou I., 2 O $^{\text {T }}$ paratypes (MNHN Pg 5901).

SHELls. — Conidae: Conus tessulatus Born, 1778. Olividae: Oliva sp.

Material eXamined. - French Polynesia. Marquesas Is, Eiao I., snorkelling 1-2 m, coll. J. Poupin, 7.IX.1997, 1 ơ $^{7} 4.3 \mathrm{~mm}$ (holotype MNHN Pg 5896). - Nuku Hiva I., Anao bay, scuba diving at night, coll. P. Laboute, 21.IX.1997, 3 ơ ơ 3.4-6.2 mm, 1 \% 2.8 mm (MNHN Pg 5897). - Nuku Hiva I., west side of Taiohae Bay, Marquesas Expedition, stn STA-NH-III, 1-3 m, 16.IX.1967, 1 o $5.3 \mathrm{~mm}, 1$ \% $5.5 \mathrm{~mm}$ (WAM C25048). — Tahuata I., FRV Marara, stn D47, 9 ${ }^{\circ} 54.3^{\prime} \mathrm{S}, 139^{\circ} 06.5^{\prime} \mathrm{W}$, dredge 48 m, 31.VIII.1990, 2 우 1.4, 2.3 mm (MNHN Pg 5439). - Ua Huka I., Teuahia bay, MUSORSTOM 9, stn $25,8^{\circ} 55.7^{\prime} \mathrm{S}, 139^{\circ} 36.7^{\prime} \mathrm{W}$, dredge 6-15 m, coll. R. von Cosel, J. Tardy \& J. Tröndlé, 16.IX-19.X.1997, 2 ㅇ 1 1.6, 7.3 mm (MNHN Pg 5898, ๆ 1.6 mm DNA H277-EF683563). - Hane bay, MUSORSTOM 9, stn $29,8^{\circ} 55.7^{\prime} \mathrm{S}, 139^{\circ} 32.0^{\prime} \mathrm{W}$, dredge 7-11 m, coll. von Cosel et al., 16.IX-19.X.1997, 1 ᄋ 3.7 mm (WAM leg. from MNHN collections). - Haavei bay, Tenoni point, "île aux Oiseaux" (Teuaua islet), MUSORSTOM 9, stn 34, c. $8^{\circ} 56.8^{\prime} \mathrm{S}, 139^{\circ} 35.7^{\prime} \mathrm{W}$, dredge $10-15 \mathrm{~m}$, coll. von Cosel et al., 16.IX-19.X.1997, 2 o $0^{7} 1.2,1.9$ mm, 2 우 2.3, $3.8 \mathrm{~mm}, 1$ additional specimen in its shell (ZRC leg from MNHN collections). - Ua Pou I., MUSORSTOM 9, stn CP1264, 9 $21.3^{\prime} \mathrm{S}, 140^{\circ} 07.7^{\prime} \mathrm{W}$, 53-57 m, 3.IX.1997, 2 o' ơ 3.2, 3.5 mm (MNHN Pg 5901, ơ 3.2 mm DNA H278-EF683564).

Distribution (Fig. 9). - French Polynesia, Marquesas Is. (Eiao I., Nuku Hiva I., Tahuata I., Ua Huka I., Ua Pou I.). Collected from the intertidal to $10-20 \mathrm{~m}$, with a single record at $53-57 \mathrm{~m}$. 


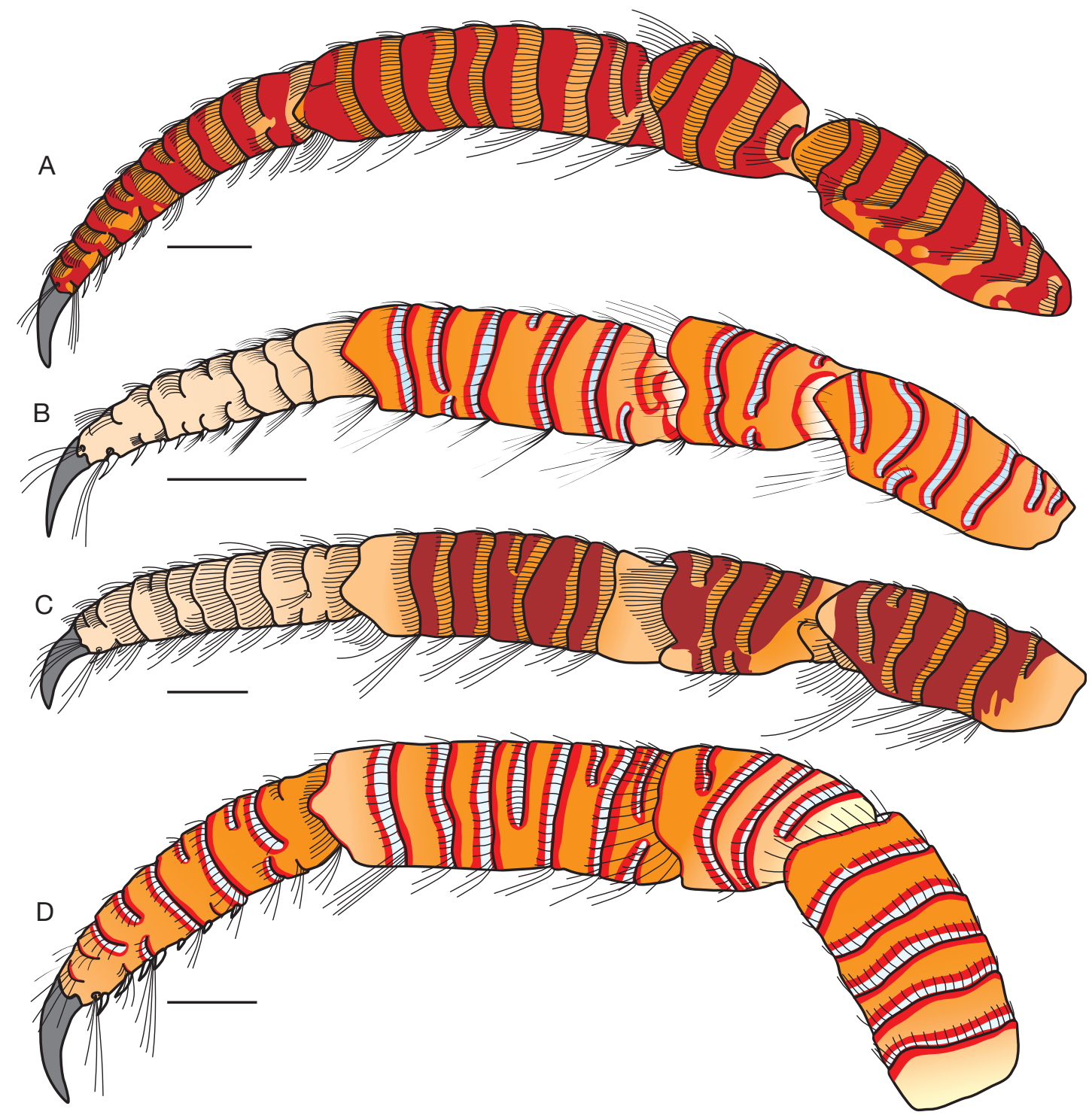

FIG. 4. - Left third pereiopod colour pattern, outer view: A, Ciliopagurus strigatus (Herbst, 1804), ơ 3.8 mm, Réunion I. (MNHN Pg 7759); B, C. tricolor (Forest, 1995), ovig. $93.3 \mathrm{~mm}$, Réunion I. (MNHN Pg 7760); C, C. vakovako Poupin, 2001, holotype ơ 4.3 mm, Marquesas Is (MNHN Pg 5896); D, C. galzini n. sp., holotype ơ $3.8 \mathrm{~mm}$ (UF Crust 10901). Scale bars: $1 \mathrm{~mm}$.

DiAGNOSIS. - Ocular peduncles 0.60-0.77 times as long as shield (average 0.70). Distal segment of antennular peduncle 0.21-0.31 times as long as shield (average $0.27)$. Ocular acicles with 3-5 terminal spines, usually 4. Chelipeds equal; outer face of chelae with 3 complete transverse striae, 1 proximal striae interrupted near ventral margin of the palm and 2 short striae situated in ventral half between striae 1-2 and 2-3. These striae are smooth or with minute spinules. Chela 0.74-0.94 times as long as shield (average 0.84 ); ratio of height to length 0.60-0.98 (average 0.74); fingers $0.44-0.63$ times as long as chela (average 0.54 ). Stridulating area with 4 distinct areas composed of parallel corneous crests; distal area the largest with 8-11 distally rounded or acute crests; 6th to 8 th crest longest, about 0.50 times as long as stridulating area. Merus of cheliped without prominent tubercle on 
ventral surface. Dactyl of third ambulatory leg 0.90-1.16 times as long as propodus (average 1.07). Posterior lobes of telson subequal to moderately asymmetrical with $2-4$ inconspicuous spines on terminal margins.

Coloration (Fig. 1C). - Antennular and antennal peduncles reddish-orange, flagella cream; ocular peduncles and ocular acicles reddish-orange, cornea black. Chelipeds (Fig. 3C) and ambulatory legs (Fig. 4C) with bright red rings alternating with narrower yellow rings. Chelipeds (Fig. 3) with red rings disposed on meri, carpi, and palms of chelae; fingers of chelae uniformly pale orange. Ambulatory legs (Fig. 4C) with red rings on meri, carpi and propodi; dactyls uniformly pale orange, terminal claws black. Shield cream with some light orange mottling on posterior half. Abdomen red, striped with undulating transverse, almost parallel yellow lines.

\section{REMARKS}

By its coloration Ciliopagurus vakovako cannot be confused with any species of the "strigatus complex" (see Fig. 1). It bears some resemblance to C. tricolor, with similar pale orange colour on the fingers of chelae and dactyls of ambulatory legs, but the coloured rings disposed on the remaining parts of these appendages are uniformly red in C. vakovako instead of being bluish white and red in $C$. tricolor.

Morphological characters used by Poupin (2001) to distinguish C. vakovako, C. strigatus and C. tricolor are not confirmed in this work by examination of more specimens of each species. The difference in the striation pattern of the outer face of chela between C. strigatus and C. vakovako (Poupin 2001: fig. 3) now clearly appears to be size related and is not confirmed for specimens of similar size (compare outer face of chelae in Figure 3A and 3C). Similarly, differences tentatively indicated by Poupin (2001) between C. vakovako and C. tricolor are not confirmed. In both species the posterior margins of both lobes of the telson can be unarmed or with few minutes spines (usually 1-4) and the proportion of the ocular peduncles are likewise in both species. In C. vakovako and C. tricolor, respectively, the mean length of ocular peduncle divided by shield length is 0.70 and 0.67 (see Table 1 and Fig. 8) and length of ocular peduncle divided by diameter of cornea is 4.60 and 4.97. The small differences between these means are not statistically significant $(\mathrm{P}<0.05)$.

In conclusion, the possibility considered by Poupin (2001) that the minor morphological dif- ferences used to separate C. vakovako, C. tricolor, and $C$. strigatus are artifacts due to comparison of specimens of unequal size is confirmed in this study after examination of more specimens. Live coloration thus remains the only confident way to separate these species.

\section{Ciliopagurus galzini n. sp. \\ (Figs 1D; 3D; 4D; 5-9)}

Ciliopagurus tricolor - Poupin 2005: 9, 23 [not Ciliopagurus tricolor Forest, 1995].

TyPe MATERIAL. - French Polynesia. Tuamotu Is, Rangiroa I., off Motu Maeherehonae, $14.9287^{\circ} \mathrm{S}, 147.8578^{\circ} \mathrm{W}$, outer slope under rocks, 6-12 m, coll. G. Paulay, 10.IX.2001, o $3.8 \mathrm{~mm}$, in Conus ?pertusus (holotype, UF Crust 10901). - Same, in Cypraea sp., 1 ơ 2.9 mm (paratype, MNHN Pg 6347, DNA H284-EF683570); 1 \% 2.2 mm, 1 \& $3.2 \mathrm{~mm}$ (paratype, UF Crust 1339, DNA H282EF683568, DNA H283-EF683569). - Same, in cavern and wall, 3-12 m, coll. G. Paulay, 10.II.2001, 1 o $3.2 \mathrm{~mm}$ (paratype, UF Crust 1742, DNA H32-EF683560).

SHELLS. - Cypraeidae: Cypraea helvola Linnaeus, 1758; Cypraea scurra Gmelin, 1791; Cypraea schilderorum (Iredale, 1939). Conidae: Conus pertusus Hwass in Bruguière, 1792.

TYPE LOCALITY. - French Polynesia (Tuamotu Is, Rangiroa I.), 3-12 m.

Etymology. - This species is dedicated to Professor René Galzin, director of CRIOBE biological research station at Moorea I. René Galzin has constantly supported our research on coral reef fauna in French Polynesia and other places in the Indo-West Pacific.

Distribution (Fig. 9). - Known from type locality only, French Polynesia (Tuamotu Is, Rangiroa I.), outer reef slope between 3 and $12 \mathrm{~m}$.

Diagnosis. - Ocular peduncles 0.68-0.77 (average 0.72 ) times as long as shield. Distal segment of antennular peduncle 0.21-0.30 (average 0.25) times as long as shield. Ocular acicles each with 3 or 4 terminal spines (unusually 2). Chelipeds equal; outer face of chela with 3 complete transverse striae, plus an additional stria proximally partly hidden behind anterior margin of carpus; striae smooth or with minute spinules. Chela 0.77-1.00 (average 0.92) times as long as shield; fingers 0.49-0.56 (average 0.52) times as long as chela. Main stridulating area with 10-12 parallel corneous crests, distally acute. Merus 


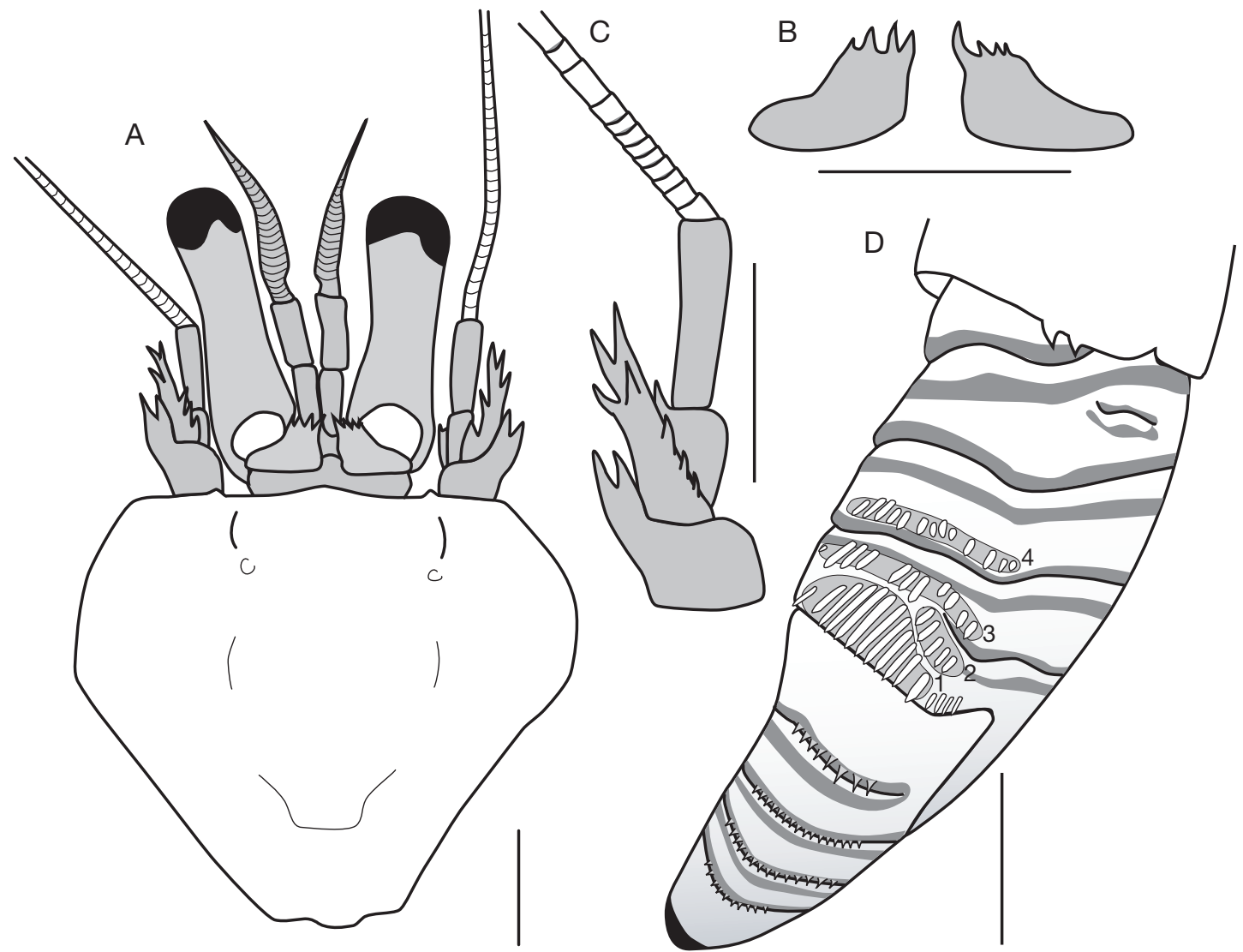

FIG. 5. - Ciliopagurus galzini n. sp., holotype ơ $3.8 \mathrm{~mm}$ (UF Crust 10901): A, shield and cephalic appendages; B, ocular scales; C, left antenna, dorsal view; D, left chela, dorsomesial face, with detail of stridulating apparatus and identification of four main areas (1-4). Scale bars: $1 \mathrm{~mm}$.

of cheliped without prominent tubercle on ventral face. Dactyl of third ambulatory leg 0.99-1.07 (average 1.04) times as long as propodus. Posterior lobes of telson subequal, unarmed or with 1-6 inconspicuous spines on terminal margins.

Coloration (Fig. 1D). - Antennular, antennal and ocular peduncles bright orange, cornea yellow. Chelipeds (Fig. 3D) and ambulatory legs (Fig. 4D) with composite coloured rings, comprised of one white median band, flanked by two bright red rings; these composite rings are set against a bright orange background. Chelipeds with composite rings on meri, carpi, and chelae including fingers. Ambulatory legs with composite coloured rings disposed on meri, carpi, propodi and dactyls; terminal claws black. Shield white; live coloration of the abdomen not known, cream after several months in preservative.

\section{DESCRIPTION}

Shield slightly wider than long (Fig. 5A). Rostrum rounded, slightly overreaching level of broadly subtriangular lateral projections; anterior margins between rostrum and lateral projections slightly concave; anterolateral margins strongly convex.

Ocular peduncles subequal or left slightly longer than right, 0.68-0.77 (average 0.72) times as long as shield, slightly constricted medially. Cornea diameter included 3.93-4.83 (average 4.55) times length of ocular peduncles. Ocular acicles well developed, subtriangular, distally truncated, armed with 3 or 4 terminal spines. Antennular peduncles reaching to distal 0.25 of ocular peduncles, when fully extended; ultimate segments $0.21-0.30$ (average 0.25 ) times as 
long as shield. Antennal peduncles slightly shorter than antennular peduncles, reaching between middle and distal 0.30 of ocular peduncles. First segment unarmed. Second segment with laterodistal angle produced, terminating in bifid spine. Third segment with strong spine at ventrodistal angle. Fourth segment with dorsodistal spine. Fifth segment unarmed. Antennal flagellum overreaching outstretched chelipeds. Antennal acicle reaching well beyond proximal margin of fifth antennal segment, terminating in 2 strong pairs of terminal and sub-terminal spines; dorsomesial margin with 2 or 3 spines.

Chelipeds equal, distal margins of carpi slightly overreaching distal margins of ocular peduncles. Chela 0.77-1.00 (average 0.92) times as long as shield, ratio of height to length 0.63-0.73 (average 0.68). Cutting edges of dactyl and fixed finger with 3 large calcareous teeth. Dactyl 0.49-0.56 (average 0.52) times as long as chela, outer face with 4 transverse striae each bearing stiff setae and minute corneous spines (Fig. 5D). Fixed finger with 3 similar transverse striae. Outer face of palm with transverse striae set with stiff setae: 3 complete striae plus a proximal stria partly covered by anterior margin of carpus and shorter striae between as illustrated on Figure 3D. Dorsomesial surface of palm with stridulating apparatus in distal half composed of parallel corneous crests disposed on 4 main areas (numbered 1 to 4 on Fig. 5D). Distomesial area (no. 1) with 10-12 crests oriented obliquely to longitudinal axis of palm, distally acute; 6th-8th crest the longest being about 0.4 length of this area; dorsolateral side of area no. 1 with 3 or 4 additional small crests. Area no. 2 much shorter, with only 4 or 5 crests near dorsal margin of palm. Areas nos 3 and 4 narrow, subparallel, each composed of 10-14 short crests, some of them reduced to corneous granules. Stria behind area no. 4 with few indistinct corneous denticles. Carpus shorter than palm bearing transverse striae set with stiff setae. Outer face with 3 main striae behind anterior margin plus an additional incomplete stria between the two first striae (Fig. 3D). Merus with 4 complete striae on outer face behind anterior margin and 1-3 additional posterior striae shorter and fragmented; ventral area depressed, without prominent tubercle; ventrolateral margin with 2 distal spines.

Ambulatory legs similar between left and right, overreaching outstretched chelipeds by length of dactyls. Relative length of segments and arrangement of striae, setae, and spines similar between second and third pereopods; transverse striae and distal margins of each segment set with stiff setae. Dactyl 0.99-1.07 (average 1.04) times as long as propodus, with strong terminal claw; ventral margin with 5-8 corneous spines, decreasing in size posteriorly, obscured by tufts of long setae; outer face with 3 or 4 main transverse striae plus a few shorter striae between. Propodus 0.76-1.02 (average 0.90) times as long as shield, with 5 or 6 main transverse striae and a few additional shorter striae between. Carpus 0.52-0.59 (average 0.55) times as long as propodus, with 3 or 4 transverse striae. Merus 0.81 0.89 (average 0.85 ) times as long as propodus, with 5 or 6 main transverse striae and few shorter striae between; outer face convex, inner face flattened, dorsal margin angular set with long setae.

Fourth pereopod semichelate. Dactyl with long setae on dorsal margin. Propodus with broad rasp consisting of several rows of corneous scales, dorsodistal margin with long setae. Carpus with dorsodistal spine, dorsal margin with long setae. Merus with few striae on outer face, dorsal and ventral margins with long setae. Fifth pereopod chelate, with rasp on propodus and dactyl. Carpus and merus subovate in cross-section.

Abdomen with 4 unpaired biramous pleopods, on left side (verified in male only). First pleopod shortest, other 3 subequal in length. Sixth abdominal tergite calcified with a deep sub-median transverse groove and a weak longitudinal median furrow, more noticeable on posterior area.

Telson with distinct lateral indentations. Posterior lobes subequal to moderately asymmetrical, terminal margins with long setae at external angles. Left lobe rounded, only slightly longer than right, lateral margin unarmed, terminal margin with 2-6 spinules (sometimes missing or indistinct); right lobe rounded, terminal margin armed with 1-3 spinules.

\section{REMARKS}

An unusual armament of the ocular acicle, only 2 terminal spines instead of the usual 3 or 4 , is observed on a single specimen out of five ( $\sigma^{7} 3.2 \mathrm{~mm}$, UF Crust 1742). 
Within the species of the "strigatus complex" C. galzini n. sp. is most closely related to C. tricolor with a similar colour pattern made of composite coloured rings disposed on an orange background. Because of this resemblance, the specimens collected at Rangiroa were first attributed to $C$. tricolor by Poupin (2005). However, when more specimens of C. tricolor were later available from Réunion Island, with photographs of live coloration, it became obvious that the specimens from Rangiroa, described herein as C. galzini n. sp., differ consistently from those collected in the western Indian Ocean in the coloration of fingers of chelae and dactyls of ambulatory legs. In C. galzini n. sp., these segments have composite coloured rings instead of being uniformly pale orange as in C. tricolor (see Figs 1B, D; 3B, D; 4B, D).

The few other morphological differences observed between some specimens of the two species, such as the aspect of transverse striae on chelae and ambulatory legs, number of spines on ventral margins of dactyls of pereopods or on terminal margins of telson, and relative length of the appendages (see morphometric analysis), are size related or within the range of intraspecific variations observed for the two species. They cannot be used confidently to separate them. A phylogenetic analysis of mitochondrial DNA sequences has been therefore undertaken to confirm the appraisal of these colour differences as valuable specific indicators (see discussion).

\section{RESULTS AND DISCUSSION}

\section{MORPHOMETRIC CHARACTERS}

Forest (1995a) indicated that the relative length of some appendages is sometimes a valuable character to separate the species of Ciliopagurus. Other studies, such as Nomura \& Anker (2005), for coral shrimps of the Alpheus gracilipes Stimpson, 1860 complex, have succeeded in confirming colour morphs as separate species by morphometric characters. These characters have therefore been indicated in the diagnosis of each species and a synthesis of all the measures made for this study is presented in Table 1, including also measurements of $C$. krempfi for comparative purposes. An ANOVA and paired tests performed on this set of data show that the third antennular

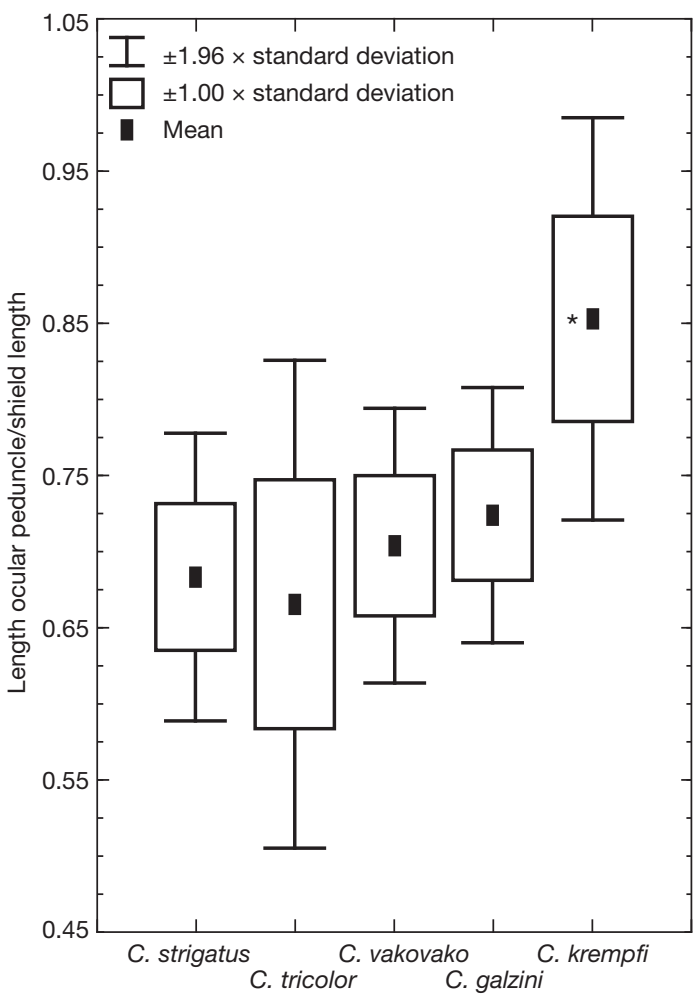

FIG. 6. - Length of ocular peduncle/shield length. Data from Table 1, means \pm 1.00 or 1.96 standard deviation, calculated for species of the strigatus species complex and Ciliopagurus krempfi (Forest, 1952): * indicates a significant difference (ANOVA and paired tests, $\mathrm{P}<0.05)$.

segment, the ocular peduncle (Fig. 6), and the dactyl of $\mathrm{P} 3$ are significantly longer $(\mathrm{P}<0.05)$ in $C$. krempfi than in the four species of the "strigatus complex". This confirms the observations made by Forest (1995a: 62) for C. krempfi and indicates that the proportion of some segments and appendages can be valuable characters to separate some species of Ciliopagurus. However, when the four species of the "strigatus complex" are considered alone, the same statistical analysis indicates no significant differences between the proportions of the segments and appendages. The slight differences in the proportions of distal antennular segment, ocular peduncle, chela, and dactyl of P3, observed between the four species of the "strigatus complex" fall within the range of intraspecific variation and cannot be used confidently 
TABLE 1. - Morphometric characters selected for Ciliopagurus Forest, 1995 species of the "strigatus complex" plus C. krempfi (Forest, 1952) for comparison. Mean values, with number of specimens and standard deviation, in parentheses. Abbreviations: sl, shield length; A, length of terminal segment of antennular peduncle/sl; B, length of ocular peduncle/sl; C, length of chela/sl; $\mathbf{D}$, length of dactyl of chela/length of chela; $\mathbf{E}$, chela length/height; $\mathbf{F}$, length of P3 dactyl/propodus; $\mathbf{G}$, length of dactyl of P3/sl. Bold figures for C. krempfi indicate means that are significantly different (ANOVA and paired tests, $\mathrm{P}<0.05$ ).

\begin{tabular}{lccccc}
\hline & \multicolumn{3}{c}{ Species of the "strigatus complex" } \\
Ratio & C. strigatus & C. tricolor & C. vakovako & C. galzini n. sp. & C. krempfi \\
\hline A (antennule) & $0.25(9,0.024)$ & $0.25(11,0.025)$ & $0.27(18,0.029)$ & $0.25(5,0.034)$ & $\mathbf{0 . 3 3}(17,0.037)$ \\
B (ocular peduncle) & $0.68(9,0.048)$ & $0.67(11,0.082)$ & $0.70(18,0.046)$ & $0.72(5,0.043)$ & $\mathbf{0 . 8 5}(17,0.067)$ \\
C (chela length) & $0.90(9,0.112)$ & $0.88(10,0.090)$ & $0.84(14,0.059)$ & $0.92(5,0.089)$ & $0.93(16,0.079)$ \\
D (chela dactyl) & $0.54(9,0.039)$ & $0.54(10,0.042)$ & $0.54(15,0.051)$ & $0.52(5,0.026)$ & $0.54(16,0.035)$ \\
E (chela proportions) & $0.68(9,0.059)$ & $0.71(10,0.053)$ & $0.74(15,0.098)$ & $0.68(5,0.043)$ & $0.73(16,0.061)$ \\
F (P3 dactyl/propodus) & $1.04(7,0.073)$ & $1.09(9,0.095)$ & $1.07(14,0.081)$ & $1.04(5,0.035)$ & $\mathbf{1 . 1 7}(15,0.153)$ \\
G (P3 dactyl length) & $0.87(9,0.068)$ & $0.85(9,0.080)$ & $0.88(14,0.062)$ & $0.94(5,0.100)$ & $0.92(16,0.152)$ \\
\hline
\end{tabular}

to separate them. If differences in morphometric characters do exist between these four species, they are small and the ranges overlap considerably; thus they must be confirmed with more measures made on larger sets of specimens.

\section{Phylogenetic ANALYSES}

We analyzed the phylogenetic relationships of the four Ciliopagurus species in the "strigatus complex" in order to confirm whether they constitute genetically distinct, non-interbreeding evolutionary units. A summary of the results is presented in Figures 7 and 8. Bayesian, likelihood, and parsimony analyses for the combined dataset and for the individual genes all yielded trees that grouped the four species into reciprocally monophyletic units. With the exception of the slowly-evolving $\mathrm{H} 3$ gene tree (which failed to resolve the ingroup species), all other analyses showed strong branch support (e.g., nonparametric bootstrap values and Bayesian posterior probabilities) for each species. There is also strong support for the monophyly of the "strigatus complex" species vis-à-vis the outgroup species. Thus the genetic analyses both confirm the close phylogenetic relationship of the "strigatus complex" species as well as strongly support the presence of four clades within this species complex. Within the species complex, the phylogenetic data indicate that $C$. strigatus, C. vakovako, and C. galzini n. sp. are more closely related to each other than to $C$. tricolor.

An important feature of the genetic analyses was the inclusion of specimens from sympatric popula- tions of C. strigatus and C. galzini n. sp. (sympatric in Rangiroa atoll) and C. strigatus and C. tricolor (sympatric at Réunion I.). The mitochondrial haplotypes of the different species are genetically distinct even in sympatry, which denotes reproductive isolation of the species. Despite the fact that the known geographic range of C. galzini n. sp. (Rangiroa atoll in the Tuamotus) is completely sympatric with the widely distributed $C$. strigatus, the two species are distinct evolutionary entities and conform to the requirements of the biological species concept. Therefore the DNA evidence agrees with observations of live coloration and confirm the taxonomic distinctness of C. galzini n. sp.

\section{SPECIES BOUNDARIES}

The geographic distribution of the four Ciliopagurus species in the "strigatus complex" is illustrated in Figure 9 based on the material examined for this work and literature records. From these results, the following hypothesis of speciation can be proposed. Ciliopagurus strigatus, the commonest species of the complex distributed from the Red Sea to the Tuamotus, represents the modern descendant of a large ancestral population. On the peripheries of its distribution, in the western Indian Ocean, eastern Tuamotus, and Marquesas, a process of peripatric speciation has separated C. tricolor, C. galzini n. sp., and $C$. vakovako (respectively) from the ancestral species. The split between $C$. tricolor and $C$. strigatus preceded the divergence of $C$. galzini n. sp. and C. vakovako from C. strigatus. While this paper does 


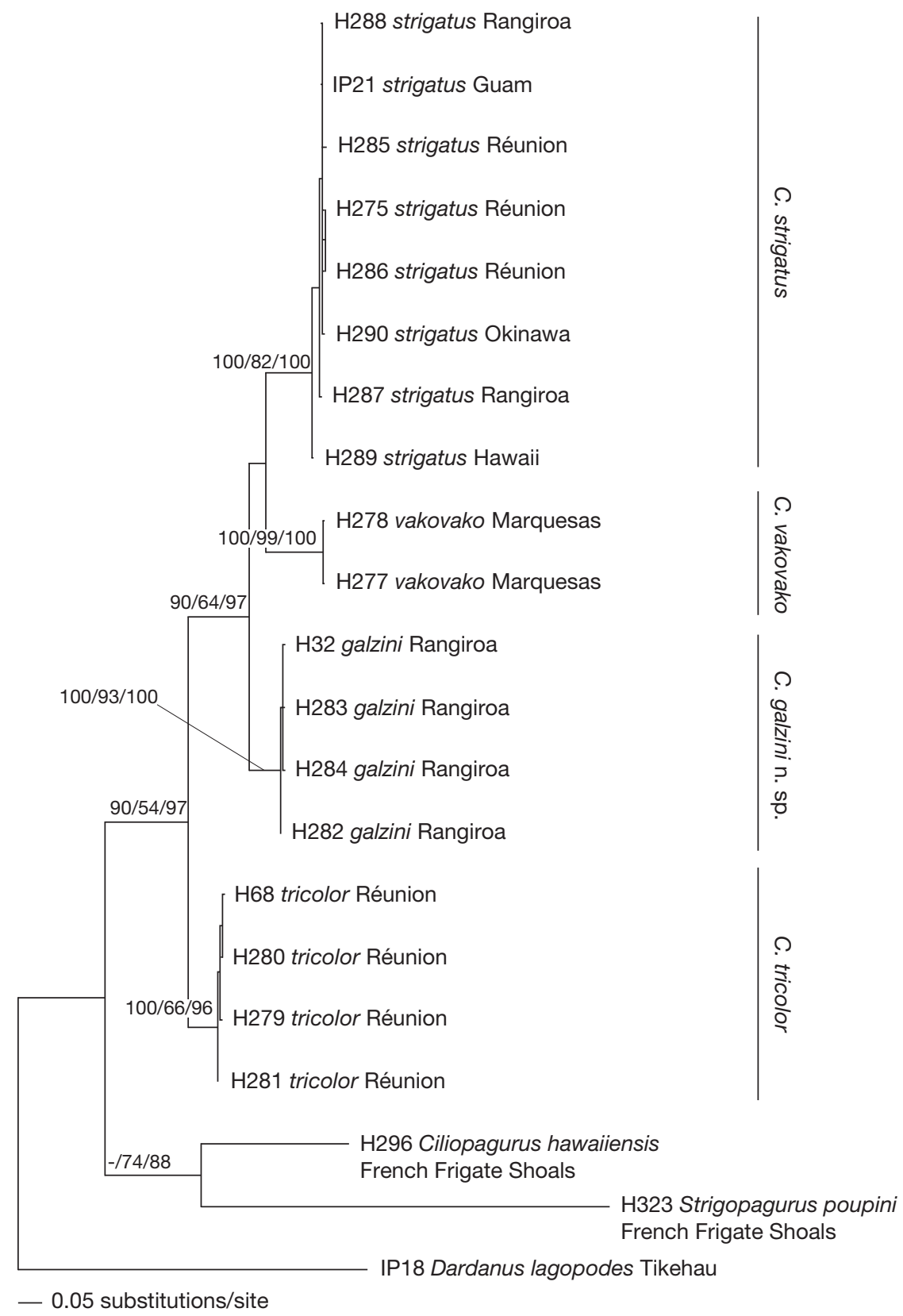

FIG. 7. - Maximum likelihood phylogram based on COI mitochondrial DNA sequences. Values above the branches correspond to parsimony bootstraps (left), maximum likelihood bootstraps (middle), and Bayesian posterior probabilities (right).

not explicitly evaluate the causes of lineage splitting, the Indian plate, separated from the Gondwana and it is possible that the divergence of $C$. tricolor may moving to the north, was situated in the middle of have happened at the Paleocene (55-65 Ma) when the Indian Ocean, therefore restricting the exchanges 


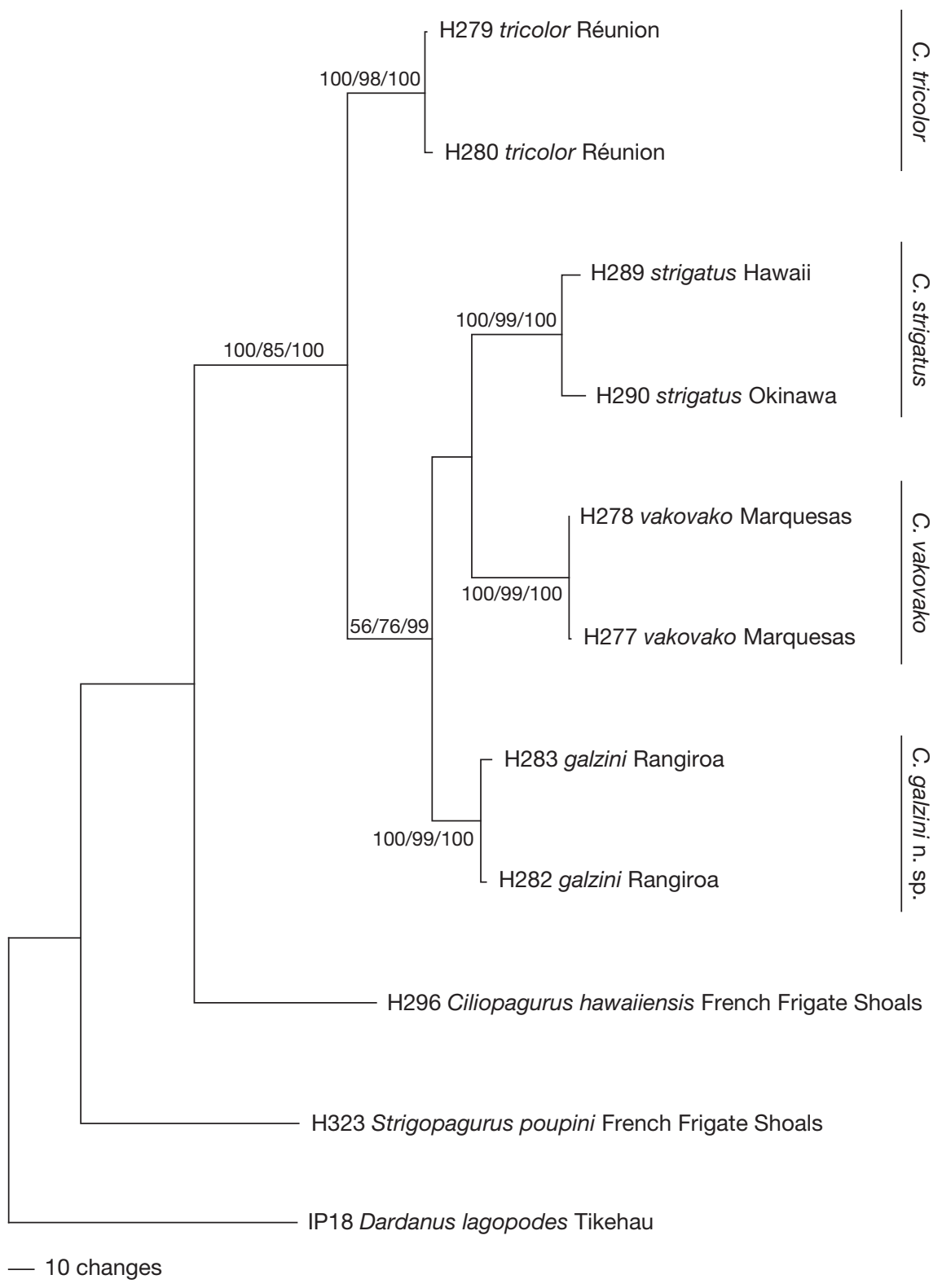

FIG. 8. - Maximum likelihood phylogram based on combined analysis of $\mathrm{COI}, 16 \mathrm{~S}$, and $\mathrm{H} 3$ genes. Support values follow the same notation as in Figure 7.

between the eastern and western Indian Ocean. Another possibility may be that diversification in the "strigatus complex" proceeded via peripatric speciation through founder speciation, a haphazard process that happens at irregular intervals. Thus, the early splitting of $C$. tricolor may have been a result of a random process of dispersal and founder speciation (Paulay \& Meyer 2002). Two of the 


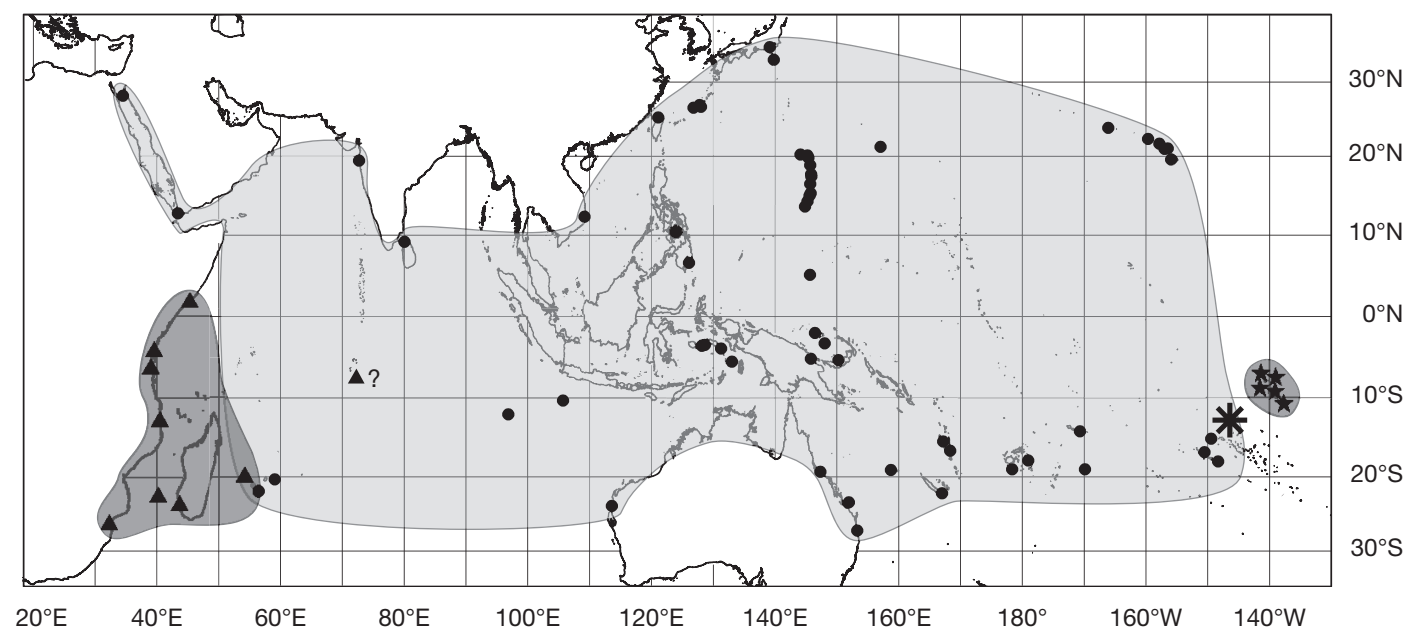

FIG. 9. - Geographic distributions of the Ciliopagurus Forest, 1995 species included in the "strigatus complex" based on the material examined for this work and literature. Light gray area is the distribution of C. strigatus (Herbst, 1804) ( ); dark gray areas are the distribution of C. tricolor (Forest, 1995) ( $\mathbf{\Delta})$ and C. vakovako Poupin, 2001 ( $\star$ ); asterisk (*) is the distribution of C. galzini n. sp. A doubtful locality for C. tricolor is indicated by " $\mathbf{\Delta}$ ?".

peripheral species, C. tricolor and C. galzini n. sp., are narrowly parapatric with C. strigatus (at Réunion I. and the Tuamotus, respectively) probably as a result of secondary overlap. The non-overlapping distributions of C. vakovako and C. strigatus may be a result of very recent speciation and insufficient time for the two species to overlap in their distributions (although the phylogenetic data does not resolve the relative timing of divergences of C. strigatus, C. galzini n. sp., and C. vakovako; see Figs $7 ; 8)$.

In the Marquesas, the process of peripatric speciation of Ciliopagurus vakovako can be explained by a single dispersal event to the Marquesas of a few members of the common C. strigatus. This suggests that the Marquesas are often separated from other western Pacific localities by some sort of dispersal barrier; this barrier can, for example, be the dominance of the westward-flowing Pacific South Equatorial Current at the latitudes occupied by the Marquesas Is $\left(5^{\circ} \mathrm{N}-15^{\circ} \mathrm{S}\right)$, restricting the dispersal of larvae from the west. A similar process of speciation is envisaged by Bernardi et al. (2002) for the coral reef damselfish Dascyllus strasburgi Klausewitz, 1960 a species of the D. trimaculatus (Rüppell, 1829) species complex, with distinct colour pattern and endemic to the Marquesas Is.

\section{SPECIES RANK ATTRIBUTED TO COLOUR MORPHS}

The colour morphs recognized in the last decades in Ciliopagurus strigatus s.l. have been all elevated to species rank with taxonomic descriptions based primarily on colour patterns. Specimens with an intermediate coloration have never been reported and all new species are geographically isolated, $C$. tricolor in the western Indian Ocean, C. vakovako in the Marquesas, and C. galzini n. sp. in the Tuamotus. In addition, the phylogenetic analysis of DNA sequences made in this study demonstrates that individuals of each species grouped into monophyletic clades, which strengthens the case for taxonomic distinctness. The sympatric co-occurrence of $C$. strigatus- $C$. tricolor and C. strigatus-C. galzini n. sp. is clear evidence that these taxa have become reproductively isolated, which meets the criterion of the biological species concept. Knowlton (1986) has already stressed the importance of colour for separating cryptic species in the Decapoda and a lot of colour morphs have been subsequently described as new species (Castro 1996; Nomura \& Anker 2005; Poupin \& Bouchard 2006; Trautwein 2007). In the alpheid shrimps, Knowlton (1986) indicates that even minor colour differences can trigger aggressive behavior between two individuals of different colour which prevent potential interbreeding and confirms the validity of these specific statuses. 


\section{Key to the Ciliopagurus Forest, 1995 SPECIES OF THE “STRIGATUS COMPLEX”, BASED ON COLOUR}

1. Chelipeds and ambulatory legs with simple coloured rings, bright red 2

- Chelipeds and ambulatory legs with coloured rings made of one bluish white median ring flanked by two bright red rings 3

2. Coloured rings present on fingers of chelae and dactyls of ambulatory legs C. strigatus (Indo-West Pacific)

- Fingers of chelae and dactyls of ambulatory legs uniformly pale orange C. vakovako (Marquesas Is)

3. Coloured rings present on fingers of chelae and dactyls of ambulatory legs C. galzini n. sp. (Tuamotu Is)

- Fingers of chelae and dactyls of ambulatory legs uniformly pale orange ... C. tricolor (Western Indian Ocean)

\section{Acknowledgements}

We thank all colleagues who provided us with samples and colour photographs: G. Paulay (Mascarene Is, Japan, Mariana Is, Niue, Hawaiian Is, French Polynesia), M. Guillaume (Réunion I.), J. Okuno (Japan). We would also like to thank O. Coleman, C. Fransen, L. B. Holthuis, M. Türkay and J. Forest, for their help in clarifying the taxonomic status of C. strigatus (Herbst, 1804), G. Paulay for helpful comments on the manuscript, and A. Crosnier, D. Defaye, and R. Cleva for their assistance during visits at the Muséum national d'Histoire naturelle, Paris. The University of Florida Phyloinformatics Cluster for High Performance Computing in the Life Sciences provided computational support for this research. R. Lemaitre and an anonymous reviewer have helped to improve the draft manuscript.

Part of this research was funded by a SYNTHESYS grant (http://www.synthesys.info) to visit Leiden Museum, a CRISP grant (http://www.crisponline. net) to visit Wallis and Futuna Is, the Agence nationale de la Recherche (France), program BIOTAS, for specimens collected at Réunion I., and NSF OCE-0221382 for DNA sequencing.

\section{REFERENCES}

Allen G. R. \& STEene R. 1994. - Indo-Pacific Coral Reef Field Guide. Tropical Reef Research, Singapore, $378 \mathrm{p}$.

ASAKURA A. 1995. - [Infraorder Anomura], in NISHIMURA S. (ed.), [Guide to the Seashore Animals of Japan with Colour Pictures and Keys]. Volume 2. Hoikusha, Osaka:
347-378, pls 93-100 (in Japanese).

Bakel van B. W. M., Jagt J. W. M. \& Fraaije R. H. B. 2003. - Ciliopagurus obesus, a new species of Oligocene hermit crab from northwest Belgium. Cainozoic Research 2 (1-2): 109-116 (dated 2002, published 2003).

BARKER F. K. \& LUTZONI F. M. 2002. - The utility of the Incongruence Length Difference Test. Systematic Biology 51: 625-637.

BARNARD K. H. 1950. - Descriptive catalogue of South African Decapod Crustacea (crabs and shrimps). Annals of the South African Museum 38: 1-837.

Bernardi G., Holbrook S. J., SCHMitT R. J., Crane N. L. \& DeMartini E. 2002. - Species boundaries, populations and colour morphs in the coral reef threespot damselfish Dascyllus trimaculatus species complex. Proceedings of the Royal Society 269: 599-605.

Castro P. 1996. - Eastern Pacific species of Trapezia (Crustacea, Brachyura, Trapeziidae), sibling species symbiotic with reef corals. Bulletin of Marine Science 58 (2): 531-554.

Colgan D. J., Mclauchlan A., Wilson G. D. F., Livingston S. P., Edgecombe G. D., Macaranas J., Cassis G. \& Gray M. R. 1998. - Histone H3 and U2 snRNA DNA sequences and arthropod molecular evolution. Australian Journal of Zoology 46: 419-437.

Debelius H. 2001. - Crustacea Guide of the World. Shrimps, Crabs, Lobsters, Mantis Shrimps, Amphipods. Second edition. IKAN, Frankfurt, $321 \mathrm{p}$.

Debelius H. \& Baensch H. A. 1994. - Marine Atlas. Mergus, Publishers of Natural History and Pet Books, Hans A. Baensch, Melle, 1215 p.

DÉRIJARD R. 1966. — Note préliminaire sur les crustacés stomatopodes et décapodes récoltés à l'île Europa du 6 au 24 avril 1964, in LEGENDRE R. (ed.), Mission scientifique à l'̂̂le Europa. Mémoires du Muséum national d'Histoire naturelle, sér. A, Zoologie, 41: 159-180.

DÉRIJARD R. 1968. — Note complémentaire sur les 
crustacés décapodes récoltés à l'île Europa (mission scientifique française du 6 au 24 avril 1964). Bulletin du Muséum national d'Histoire naturelle, 2e sér., 39 (6): 1241-1248 (dated 1967, published 1968).

Farris J. S., Källersjö M., Kluge A. G. \& Bult C. 1994. - Testing significance of incongruence. Cladistics 10 (3): 315-319.

Fielding A. \& Robinson E. 1987. - An Underwater Guide to Hawai í. University of Hawaii Press, Honolulu, $156 \mathrm{p}$.

Folmer O., Black M., Hoeh W., Lutz R. \& VRijenHOEK R. 1994. - DNA primers for amplification of mitochondrial cytochrome c oxidase subunit I from diverse metazoan invertebrates. Molecular Marine Biology and Biotechnology 3: 294-299.

FOREST J. 1952a. - Notes préliminaires sur les Paguridae (Crustacés, Décapodes) des côtes occidentales d'Afrique. I. Définition de Pseudopagurus gen. nov. et de Trizopagurus gen. nov. Bulletin du Muséum national d'Histoire naturelle, 2e sér., 24 (3): 254-256.

Forest J. 1952b. - Contributions à la révision des crustacés Paguridae. I. Le genre Trizopagurus. Mémoires du Muséum national d'Histoire naturelle, série A, Zoologie, 5 (1): 1-40.

FOREST J. 1995a. - Crustacea Decapoda Anomura: révision du genre Trizopagurus Forest, 1952 (Diogenidae) avec l'établissement de deux genres nouveaux, in Crosnier A. (ed.), Résultats des campagnes MUSORSTOM, volume 13. Mémoires du Muséum national d'Histoire naturelle 163: 9-149.

FOREST J. 1995b. - Crustacea Decapoda Anomura: Présence du genre Ciliopagurus Forest, 1995 (Diogenidae) au Badénien (Miocène moyen): C. substriatiformis (Lörenthey, 1929), in Crosnier A. (ed.), Résultats des campagnes MUSORSTOM, volume 13. Mémoires du Muséum national d'Histoire naturelle 163: 151-154.

Gosliner T. M., Behrens D. W. \& Williams G. C. 1996. - Coral Reef Animals of the Indo-Pacific. Animal Life from Africa to Hawai' $i$, Exclusive of the Vertebrates. Sea Challengers, Monterey, California, $314 \mathrm{p}$.

Grant T. \& Kluge A. G. 2003. - Data exploration in phylogenetic inference: scientific, heuristic, or neither. Cladistics 19: 379-418.

HAIG J. \& BALl E. E. 1988. - Hermit crabs from north Australian and eastern Indonesian waters (Crustacea, Decapoda, Anomura, Paguroidea) collected during the 1975 Alpha Helix expedition. Record of the Australian Museum 40 (3): 151-196.

HERBST J. F. W. 1804. - Versuch einer Naturgeschichte der Krabben und Krebse nebst einer systematischen Beschreibung ihrer verschiedenen Arten. Gottlieb August Lange, Berlin \& Stralsund, 50 p., pls 59-62.

Hilgendorf F. 1879. - Die von Hrn. W. Peters in Moçambique gesammelten Crustaceen. Monatsbericht der Königlichen Preußischen Akademie der Wissenschaften zu Berlin 1878: 782-851, pls 1-4 (dated 1878, published 1879).

HoOver J. 1998. - Hawai is's Sea Creatures. A Guide to Hawai 'i's Marine Invertebrates. Mutual Publishing, Honolulu, 366 p.

Jones D. \& Morgan G. 2002. - A Field Guide to the Crustaceans of Australian Waters. Western Australian Museum Book, Reed, Chatswood, 224 p.

KATO S. \& OKUnO J. 2001. - Shrimps and Crabs of Hachijo Island. Tbs-Britannica Co., Tokyo, 157 p.

KAWAMOTO T \& OKUnO J. 2003. - Shrimps and Crabs of Kume Island, Okinawa. Hankyu Communications, Tokyo, 173 p.

KNOWLTON N. 1986. - Cryptic and sibling species among the decapod Crustacea. Journal of Crustacean Biology 6: 356-363.

Laboute P. \& Richer de Forges B. 2004. - Lagons et récifs de Nouvelle-Calédonie. Éditions Catherine Ledru, Nouméa, 520 p.

McLaughlin P. A. 1997. - Infraorder Anomura, hermit crabs, in Richmond M. D. (ed.), A Guide to the Seashores of Eastern Africa and the Western Indian Ocean Islands. Swedish International Development Cooperation (SIDA), Department for Research Cooperation, SAREC, Stockholm: 216-221.

McLaughlin P. A., Rahayu D. L., Komai T. \& Chan T.-Y. 2007. - A Catalog of the Hermit Crabs (Paguroidea) of Taiwan. National Taiwan Ocean University, Keelung, viii $+365 \mathrm{p}$.

Meyer C. P. 2003. - Molecular systematics of cowries (Gastropoda: Cypraeidae) and diversification patterns in the tropics. Biological Journal of the Linnean Society of London 79: 401-459.

MinEMIZU R. 2000. - [Marine Decapod and Stomatopod Crustaceans Mainly from Japan]. Bun-ichi, Sogo Shuppan, Tokyo, 344 p. (in Japanese).

NOMURA K. \& ANKER A. 2005. - The taxonomic identity of Alpheus gracilipes Stimpson, 1860 (Decapoda: Caridae: Alpheidae), with descrition of five new cryptic species, from Japan. Crustacean Research 34: 104-139.

Nomura K., Kamezaki N., Hamano T. \& Misaki H. 1988. - [The Guide Book of Marine Animals and Plants of Okinawa. Volume 8 - Crustacea (Macrura and Anomura)]. Southern Press, Okinawa, 232 p. (in Japanese).

OKUNO J. \& ARIMA H. 2006. - Additional records of inshore hermit crabs (Crustacea: Decapoda: Anomura) from Izu-ohshima Island, the northern Izu Islands, Japan. Bulletin of the Biogeographical Society of Japan 61: 29-43.

OKUNO J., TAKEDA M. \& YOKOTA M. 2006. — [Inshore hermit crabs (Crustacea: Decapoda: Anomura) collected from Izu oceanic park, eastern coast of Izu peninsula, Japan]. Memoirs of the National Science Museum 41: 145-171 (in Japanese).

Palumbi S. R. 1996. — Nucleic acids II: the polymerase chain reaction, in Hillis D. M., Moritz C. \& MABLE 
B. K. (eds), Molecular Systematics. Second edition. Sinauer and Assoc., Sunderland: 205-246.

Paulay G. \& MeYer C. 2002. - Diversification in the tropical Pacific: comparisons between marine and terrestrial systems and the importance of founder speciation. Integrative and Comparative Biology 42: 922-934.

Pérez-Losada M., Høeg J. T., \& Crandall K. A. 2004. - Unraveling the evolutionary radiation of the thoracican barnacles using molecular and morphological evidence: a comparison of several divergence time estimation approaches. Systematic Biology 53 (2): 244-264.

POSADA D. \& CRANDALL K. A. 1998. - MODELTEST: testing the model of DNA substitution. Bioinformatics 14: 817-818.

PoupIN J. 1996. - Atlas des crustacés marins profonds de Polynésie française. Récoltes du navire Marara, 1986/1996. Rapport scientifique du Service mixte de Surveillance radiologique et biologique, Montlhéry, 59 p., pls 1-20.

PouPIN J. 2001. - New collections of Ciliopagurus from French Polynesia, with the description of a new species from the Marquesas Islands (Crustacea: Decapoda: Anomura: Diogenidae). The Raffles Bulletin of Zoology 49 (2): 291-300.

PoupIN J. 2005. - Systématique et écologie des crustacés décapodes et stomatopodes de Polynésie française. Mémoire d'habilitation à diriger des recherches, Université de Perpignan, France, 115 p.

Poupin J. \& Bouchard J. M. 2006. - The eastern Pacific species of the genus Calcinus Dana, 1851, with description of a new species from Clipperton atoll (Decapoda, Anomura, Diogenidae). Zoosystema 28 (2): 465-486.

Ribes-Beaudemoulin S., Soriano T. \& Caratini J.
2002. - Merveilles sous-marines. La vie récifale à la Réunion. Tecnograph S.A., Bergamo, 191 p.

Richer de Forges B., Poupin J. \& Laboute P. 1999. La campagne MUSORSTOM 9 dans l'archipel des îles Marquises (Polynésie française). Compte rendu et liste des stations, in Crosnier A. (ed.), Résultats des campagnes MUSORSTOM, Volume 20. Mémoires du Muséum national d'Histoire naturelle 145: 9-29.

RONQUIST F. \& HUELSENBECK J. P. 2003. - MRBAYES 3: Bayesian phylogenetic inference under mixed models. Bioinformatics 19: 1572-1574.

SAKAI K. 1999. - J. F. W. Herbst collection of decapod Crustacea of the Berlin Zoological Museum, with remarks on certain species. Naturalists, Publications of Tokushima Biological Laboratory, Shikoku University 6: $1-45,21 \mathrm{pls}$.

SwOFFORD D. L. 2002. - PAUP*: Phylogenetic Analysis Using Parsimony ( ${ }^{*}$ and Other Methods), version 4.0b10. Sinauer, Sunderland (computer program).

TAKEDA M. 1994. - Crustaceans, in OKUTANI T. (ed.), [Animal Life on Coral Reefs]. Field Books no. 9. YamaKei, Tokyo: 191-232 (in Japanese).

Trautwein S. E. 2007. - Four new species of coral crabs belonging to the genus Tetralia Dana, 1851 (Crustacea, Decapoda, Brachyura, Tetraliidae). Zootaxa 1450: 1-20.

Tudge C. C. 1995. - Hermit Crabs of the Great Barrier Reef and Coastal Queensland. School of Marine Science, The University of Queensland; Backhuys Publishers, Leiden, $40 \mathrm{p}$.

Yoder A. D., IRWIN J. A \& PAYSEUR B. 2001. — Failure of the ILD to determine data combinability for slow loris phylogeny. Systematic Biology 50: 408-424.

YU H. P. \& FOO K. Y 1991. — [Hermit Crabs of Taiwan]. S. C. Publishing Inc., Taipei, 78 p. (in Chinese). 